\title{
The protective effect of Nigella Sativa oil on Penconazole induced -renal toxicity in adult albino rats: Histological, Immunohistochemical and Biochemical study
}

Article

\author{
${ }^{1}$ Nadia S. Khair and ${ }^{2}$ Nermeen M. Nooreldien \\ ${ }^{1}$ Histology and Cell Biology Department, ${ }^{2}$ Anatomy and Embryology Department, Faculty of \\ Medicine, Menoufyia University, Egypt
}

\begin{abstract}
Background: Penconazole is widely used triazole fungicide. It is used in agriculture, in human and veterinary medicine. High doses of penconazole causing nephrotoxicity and renal damage. Nigella sativa (black seed) is one of the native plants. It has anti-inflammatory, antidiabetic and anti-cancerous properties.

Aim: This work aimed to evaluate the effect of Nigella sativa oil on Penconazole induced renal toxicity in a rat model.

Material and Methods: Sixty male adult albino rats were used. They were divided into equal four groups. Group I (control): rats were received distilled water Group II (N. sativa): rats were given orally $0.2 \mathrm{ml} \mathrm{N}$. sativa oil $/ 100 \mathrm{~g}$ b. wt. three days/ week for four weeks.

Group III(PEN -treated): the animals were received intraperitoneally $67 \mathrm{mg}$ penconazole $/ \mathrm{kg} \mathrm{b}$. wt. three days/week for four weeks. Group IV(PEN+ N.sativa): rats were given penconazole $(67 \mathrm{mg} / \mathrm{kg} \mathrm{b.w})$ and N. sativa oil $(0.2 \mathrm{ml} / 100 \mathrm{~g})$ simultaneously three days weekly for four weeks. At the end of the experiment, kidney tissues were prepared for biochemical, immunohistochemical, light and electron microscopic studies.

Results: Histological examination of penconazole treated group revealed glomerular atrophy, widening of the subcapsular space and hypercellularity of the glomerular cells. Detachment of podocytes and disruption of their processes resulted in impairment of the blood renal barrier. Tubular degeneration and necrosis were confirmed by significant decrease in Bcl 2 immune marker. An increase in activity of intercalated cells of cortical collecting tubules was an indication of metabolic acidosis. Renal fibrosis was confirmed by an significant increase in $\alpha$ SMA and collagen fibers. Biochemical study revealed an increase in MDA level, decrease in both superoxide dismutase (SOD) and catalase (CAT). These changes were reserved by concomitant administration of Nigella sativa oil.
\end{abstract}

Conclusion: The antioxidant properties of Nigella sativa could be attributed in ameliorating penconazole-induced nephrotoxicity in rats.

Received: 20 October 2018, Accepted: 25 October 2018

Key Words: Atrophy, intercalated cells, fibrosis, Penconazole, podocytes.

Corresponding Author: Nadia S. Khair, MD, Histology Department, Faculty of Medicine, Menuofiya University, Egypt, Tel.: +2 048 2286683, E-mail: amarsmile2007@yahoo.com

ISSN: $1110-0559$, Vol. 42, No. 1

\section{INTRODUCTION}

Penconazole [1-(2-(2,4-dichlorophenyl)- pentyl)-1H1,2,4-triazole], a systemic triazole fungicide is a widely used fungicide with effective preventive and curative applications especially for powdery mildew disease in crops. It belongs to conazoles, a class of azole-based fungicides which widely used in agriculture as well as in human and veterinary medicine applications for the treatment of local and systemic fungal diseases ${ }^{[1]}$.

The World Health Organization (WHO) recorded that there are 3 million cases of pesticides poisoning in each year and up to 220,000 deaths ${ }^{[2]}$ Moreover, previous epidemiological studies have reported a causal connection between human exposure to pesticides and a number of health outcomes including endocrine disturbing effects ${ }^{[2]}$, mutagenicity ${ }^{[3]}$, neurotoxicity ${ }^{[4]}$ and carcinogenicity ${ }^{[5]}$.
In a previous study, penconazole (PEN) has been shown to be toxic to the male reproductive system of rats $^{[6]}$ In addition, further studies recently demonstrated that penconazole is a potent hepatotoxic and cardiotoxic fungicide in $\operatorname{rats}^{[7,8]}$. Toxicological studies have shown that penconazole has a great oral absorption, a wide body distribution and its excretion is mainly via the urine. Since the kidney is the major organ for xenobiotics excretion, renal cells are thus exposed to high doses of metabolites, causing nephro-toxicity and renal damage ${ }^{[9]}$.

Nigella sativa (N. sativa) is an annual herb belongs to Family Ranunculaceae. It grows in Mediterranean countries and it is one of the native plants which are widely distributed in Egypt ${ }^{[10]}$. Black seeds are ascribed to have many medicinal properties in traditional medicine. It is effective in relieving many disease symptoms as it possess 
antimicrobial ${ }^{[11]}$ anti-diabetic ${ }^{[12]}$ anti-inflammatory ${ }^{[13]}$ antimalarial $^{[14]}$ and anti-cancerous effects ${ }^{[15]}$

\section{MATERIALS AND METHODS}

A total of $60-$ adult male albino rats weighting $251 \pm 3 \mathrm{~g}$ were used in this study. They were purchased from the breeding center of experimental animals at Helwan University, Helwan, Egypt. The animals were kept in the laboratory under constant temperature $\left(24 \pm 2{ }^{\circ} \mathrm{C}\right)$ throughout the experimental work. They were maintained on a standard rodent pellets and water was available ad libitum. Maintenance of animals and experimental procedures was approved by the animal ethical committee in accordance with the guide for care and use of laboratory animals of Menoufia University, Egypt.

\section{Chemicals}

Penconazole is a triazole fungicide $(\mathrm{C} 13 \mathrm{H} 15 \mathrm{Cl} 2 \mathrm{~N} 3)$. The commercial formulation studied in this work was Topas VR, which contained $100 \mathrm{~g} / \mathrm{L}$ of penconazole, the active ingredient, and was produced by Syngenta Company (Bale, Suisse). The fungicide was obtained from Segma Chemical Company, Cairo, Egypt.

N. sativa oil was obtained from Cairo Pharmaceutical and Chemical Industries Company, Egypt, in containers of $20 \mathrm{ml}$.

\section{Experimental design}

Animals were randomly divided into equal four groups of 15 each as follows:

Group I (control): rats were received distilled water.

Group II(N. sativa): rats were orally given N. sativa oil at a dose of $0.2 \mathrm{ml} / 100 \mathrm{~g}$ body weight, once per day for three days/week for four weeks ${ }^{[16]}$

Group III(PEN -treated): the animals were received penconazole intraperitoneally at a dose of $67 \mathrm{mg} / \mathrm{kg}$ body weight (1/30 LD50), once per day for three days/week for four weeks ${ }^{[17]}$.

Group IV(PEN+ N. sativa): rats were given penconazole $(67 \mathrm{mg} / \mathrm{kg} \quad$ b.w $)$ and $\mathrm{N}$. sativa oil $(0.2 \mathrm{ml} / 100 \mathrm{~g})$ simultaneously three days weekly for four weeks.

All over the experiment, the animals were noticed for food habits and physical activities. At the end of the experiment and after four weeks of treatment, animals from treated and control groups weighted and sacrificed by cervical dislocation. Blood samples were collected into heparin coated tubes and centrifuged at $2200 \mathrm{~g}$ for $10 \mathrm{~min}$. Plasma samples were stored at $-20 \mathrm{c}$ until analysis. Kidney tissues were dissected out, weighted and specimens were prepared for biochemical, light and electron microscopic studies.

\section{Biochemical study: \\ 1-Urea and creatinine}

Concentrations of urea and creatinine in plasma were estimated spectro- photometrically using commercial kits (Bio Merieux, Marcy-l'Etoile, France)

\section{2-Renal oxidative stress markers}

For determination of antioxidant enzymes, kidney tissues were removed and homogenized in potassium phosphate buffer solution ( $50 \mathrm{mM}, \mathrm{pH} 7.5)$ using a PotterElvehiem homogenizer to give a $10 \%$ homogenate. Homogenates were centrifuged at $1500 \mathrm{~g}$ for $10 \mathrm{~min}$ at $4^{\circ} \mathrm{C}$; supernatant was recovered, placed on ice, and immediately used for the determination of superoxide dismutase (SOD), catalase (CAT) and Malondialdehyde (MDA). The activity of SOD was determined according to the method of Nishikimi et al. ${ }^{[18]}$. The principal of this method depends on the ability of SOD to inhibit the power of phenazine methosulphate-mediated to reduce the nitroblue tetrazolium. CAT activity was assayed according to the method of Aebi ${ }^{[19]}$. Catalase activity was determined from the rate of decomposition of $\mathrm{H} 2 \mathrm{O} 2$. MDA, as a marker for lipid peroxidation was measured colorimetrically in kidney homogenate according to the method of Ohkawa ${ }^{[20]}$.

\section{Light microscopic study:}

Specimens for light microscopic examination were fixed in $10 \%$ neutral formal saline for $24 \mathrm{~h}$, dehydrated in ascending grades of alcohol, cleared and embedded in paraffin. Sections ( $5 \mu \mathrm{m}$ thick) were cut with a microtome and subjected to H\&E staining and Masson's trichrome for detection of collagen fibers ${ }^{[21]}$. For immuno-histochemical localization of Bcl-2 (marker ofapoptosis) and alpha smooth muscle actin, $\alpha$ - SMA (marker of mesenchymal cells), fixed wax sections were stained using the avidinbiotin peroxidase method. Formalin-fixed paraffinembedded tissue sections were deparaffinized, endogenous peroxidase activity was blocked with $\mathrm{H}_{2} \mathrm{O}_{2}$ in methanol and the sections were heated in $0.01 \mathrm{~mol} / \mathrm{l}$ citrate buffer in a microwave pressure cooker for 20 minutes. The slides were allowed to cool to room temperature, and nonspecific binding was blocked with normal horse serum for 20 minutes at room temperature. Anti-Bcl-2 and antialpha smooth muscle actin monoclonal antibodies were used for detection of Bcl-2 and $\alpha$ - SMA respectively. Counterstaining was performed using Mayer's hematoxylin (Cat. No. 94585, BioGenex, Menarini Diagnostics, Antony, France $)^{[22]}$. For evaluation of each marker, morphometric analysis of optical density of BCL-2 and $\alpha$-smooth muscle actin were performed on rat kidney.

\section{Transmission electron microscope:}

For transmission electron microscope (TEM) examination, kidney specimens $(1 \mathrm{~mm} 3)$ were cut and fixed in $3 \%$ glutaraldehyde for $24 \mathrm{~h}$ with $0.1 \mathrm{~mol} / 1 \mathrm{PBS}$ at $4^{\circ} \mathrm{C}$. The sections were dehydrated in a series of ethanol 
rinses, cleared with propylene oxide, and embedded in epon. Semi-thin sections were cut and stained with toluidine blue. Ultrathin sections were cut and stained with uranyl acetate and lead citrate. The ultra-structure of the tissues was examined under a Jeol electron microscope ${ }^{[23]}$. TEM processing and examination were carried out at the Electron Microscopy Unit, Faculty of Science, Menoufia University.

\section{Statistical analysis:}

The results were expressed as mean \pm SD of different groups. The differences between the mean values were evaluated by ANOVA followed by Student's t- test using Minitab 12 computer program (Minitab Inc., State Collage, P.A, USA ).

\section{RESULTS}

\section{Change in body and kidney weights}

At the start of the experiment, all animals showed normal physical activity and normal food intake. All over the period of the experiment, the animals of the control and Nigella sativa oil (Group I \& II) showed no change in their physical activity or food intake. Animals of penconazole -treated group (Group III) showed marked decrease in their physical activity and became lethargic and rapidly deteriorating till the end of the study. While animals in the protected group (Group IV) showed nearly normal physical activity with average food consumption.

Exposure of albino rats to penconazole led to a significant decrease in the body weight of animals compared to the control $(P<0.05)$. A significant increase in body weight was observed in animals treated with penconazole +Nigella sativa compared to PEN group $(P<0.05)$. Animals given Nigella sativa alone did not show significant differences in body weight when compared to the control (Table 1) (Histogram 1a). Regarding kidney weight, there were no significant differences in kidney weights between N. sativa and treated rats (Table 1, Histogram 1b).

\section{Biochemical parameters (kidney function tests)}

Concerning the plasma urea concentration, control group and the corresponding N. sativa group (group I \& II) showed no statistically significant difference $(p>0.05)$. Compared to control group, animals of penconazole treated group (Group III) showed a significant increase $(p<0.001)$ in their plasma urea concentration at the end of the study. Compared to the treated group (Group III), animals of N. sativa group (Group IV) showed a significant decrease in plasma urea concentration $(p<0.001)$ (Table 2). Concerning the plasma creatinine concentration, control and N. sativa groups (group I \& II) showed no statistically significant difference $(p>0.05)$. animals of penconazole treated group (Group III) showed a highly significant increase $(p<0.001)$ in their plasma creatinine concentration when compared to the control group. Compared to the treated group (Group III), animals of the protected group (Group IV) showed a significant decrease in plasma creatinine concentration $(p<0.001)$ (Table 2, Histograms $2 \mathrm{a}$ and $2 \mathrm{~b}$ respectively).

\section{Histological results:}

\section{$H \& E$ and Toluidine blue stained sections:}

Examination of the renal cortex of control and $\mathrm{N}$. sativa groups (group I, II) revealed renal corpuscles with glomerular tuft of capillaries and subcapsular space. Proximal convoluted tubules (PCTs ) with a narrow lumen, basal nuclei and deeply acidophilic cytoplasm were seen. Distal convoluted tubules(DCTs) with a wide lumen, apical nuclei and less acidophilic cytoplasm appeared (Figs.1, 2).

Semithin sections of the renal cortex revealed renal corpuscle, formed of a lobulated capillary tuft ( glomerulus) inside the Bowman's capsule. The Bowman's capsule is formed of outer parietal layer with simple squamous epithelium and inner visceral layer lined with podocytes. Bowman's spaceis seen in -between the parietal layer and the visceral layer. The glomerular capillary is lined by endothelial cells and separated by mesangial cells and an amorphousmatrix (Fig. 3).PCT cells with large vesicular nuclei and well developed brush border was seen. Cortical collecting tubules lined by pale principal cells and darkly stained intercalated cells with apical cytoplasmic bleb were also present (Fig.4)

Compared with the control group, examination of the renal cortex ofPenconazole treated group (group III) showed many forms of tubular and glomerular damage. Renal corpuscle with glomerular atrophy, widening of the subcapsular space and extraglomerular aggregation of darkly stained cells were seen in some renal corpuscles . Some tubules showed vacuolation of its epithelial cells, whereas other tubules revealed necroting epithelium (pyknosis and karyolysis) and acidophilic cast in their lumen (Fig.5).The interstitium of the renal cortex revealed hemorrhage (Fig.5) and hypercellularity (Fig.6).

Penconazole - treated group showed thin epithelial lining of some renal tubular cells with flattening of its nuclei whereas, epithelium of other tubules was denuded. Obliterated glomerular capillaries were also present (Fig.7). The renal cortex from Penconazole - treated group showed cortical collecting tubule that have many intercalated cells, some of these cellshad apical cytoplasmic blebbing and others were binucleated (Fig.8).

Semithin sections of the renal cortex of Penconazole treated group revealedatrophied glomerulus with widening of Bowman's space and presence of degenerated podocytes inside the subcapsular space (Fig.9). In addition, the renal cortex of this group showed hypercellularity of glomerular cells with obliteration of the subcapsular space.Some tubular cells lack the nuclei and others with deeply stained nuclei were also observed (Fig.10). 
On the other side, examination of PEN $+\mathrm{N}$. sativa group (group IV) revealed a positive correlation between Nigella Sativa oil and Penconazole with marked reduction of the toxic effect on the kidney. Normal glomeruli were seen. Some tubules were lined with epithelial cells, having dark nuclei and deeply acidophilic cytoplasm . However, epithelial cells lining other tubules had vesicular nuclei and pale cytoplasm.Some tubules lack lumen were also present (Fig.11).

In semithin sections of the renal cortex of PEN + $\mathrm{N}$. sativa group, normal appearance of the glomerular capillaries and subcapsular space were observed (Fig.12). PCT cells with less developed brush border and collecting tubule with intercalated cells were also seen (Fig.13).

\section{Masson Trichrome stain}

Masson Trichrome stained kidney sections of control and N. sativa (group I, II) showed presence of minimal amountof collagen fibers (appeared as tinge of blue colored strips) in the interstitium and in between the glomerular capillaries. The basal lamina was positively stained (Fig.14) (Table 6).

In PEN- treated (group III), collagen fibers were increased in the interstitium and in between the the glomerular capillaries (Fig.15, Table 6). However, collagen fibers were decreased, when N. sativa was given to rats in PEN +N. sativa (group IV ) (Fig.16) (Table 6).

\section{Immunohistochemicalstudy}

Table(3) shows the expression of Bcl-2 and $\alpha$ - SMA in the kidneys of the different experimental groups. Regarding Bcl-2 immune-marker expression, kidney tissue obtained from Penconazole-treated rats showed negative expression of Bcl-2 in the basal portion of tubules and inside the glomeruli in comparison with the control group. However, treatment of animals with $\mathrm{PEN}+\mathrm{N}$. sativa up-regulated the expression of Bcl-2. The expression was detected in most of the basal portion of the renal tubules and inside the glomeruli (Fig.1) (graph3). Regarding $\alpha-$ smooth muscle actin immune-marker expression, kidney sections of control and N. sativa groups showed moderate positive reaction in the blood vessels and in the glomeruli of the renal corpuscles. In PEN treated group, $\alpha$ - smooth muscle actin immune-marker expression was strong and significantly increased in interstitial fibroblasts, in the wall of blood vessels and in the renal glomeruli. However, alpha SMA immunereaction became significantly recovered (moderate expression) in $\mathrm{PEN}+\mathrm{N}$. sativa group in comparison with PEN-treated group (Fig.18) (Histogram3).

\section{Transmission Electron Microscopic study}

Ultra-thin sections of kidney of control and N. sativa groups, revealed Podocyte with euchromatic nucleus and having primary and secondary processes, wrapped the glomerular capillaries. The glomerular basement membrane is intact and uniform. The capillary endothelial cells showed euchromatic nucleus (Fig.19). PCT cell had euchromatic nucleus, apical microvilli,electron dense lysosomes and basally located numerous longitudinally arranged mitochondria (Fig.20).

Moreover, cortical collecting tubule showed principal cells with electron lucent cytoplasm, small mitochondria and basal infoldings and intercalated cell with electron dense cytoplasm, scattered mitochondria, apical microvilli and numerous apical vesicles. Presence of tight junction between the principal cell and the intercalated cell and blood capillaries within the interstitium were also present (Fig.21).

Ultra-thin sections of kidney of Penconazole- treated group showed disruption of the wall of blood capillaries and detachment of podocytes with disruption of its processes (Fig.22). Whereas, PCT cell with destruction of its microvilli, few mitochondria and numerous lysosomes were noticed (Fig.23).However, normally appearing DCT cells were seen (Fig.24). Hypercellularity of the interstitium was also observed (Fig.24).In addition, collecting tubule with numerous electron dense intercalated cells and increase in apical organelle - free cytoplasmic blebbing was also observed (Fig.25).

In PEN+ N. sativa group, ultra-thin sections of kidney showed intact vesicular nucleus of podocyte and nearly intact glomerular basement membrane (Fig.26). While PCT cell with disrupted basement membrane and basal membrane infoldings was present (Fig.27).

\section{Lipid peroxidation and antioxidant enzymes}

Data in table (4) showed that penconazole treatment exhibited a significant increase in the level of MDA (the marker of lipid peroxidation) Significant decrease in the activities of the antioxidant enzymes, superoxide dismutase (SOD) and catalase (CAT), were observed in rats treated with penconazole. On the other hand, rats treated with PEN and $\mathrm{N}$. sativa showed a decrease in MDA and an increase in the antioxidant status (SOD, CA). (Histograms 4a and 4b).

\section{Morphometric results}

\section{Renal corpuscle measurements:}

Control and the corresponding N. sativa groups (I \& II) showed no statistically significant difference $(p>0.05)$ regarding renal corpuscle and Bowman's space diameters. Comparing with the control group, penconazole treated group (group III) showed a significant decrease $(p<0.05)$ in the diameter of the renal corpuscle $(p<0.001)$. However, Bowman's space showed a significant increase in diameter $(p<0.001)$. N. sativa administration greatly improved the morphometric results concerning the diameter of the renal corpuscle and diameter of the Bowman's space.

So PEN+ N. sativa group (group IV), showed a nonsignificant difference $(p>0.05)$ when compared to the control group (Table 5) (Histogram 5) 


\section{Percentage of surface area of collagen fiber deposition}

Control and the corresponding N. sativa groups (I \& II) showed no statistically significant difference $(p>0.05)$ concerning the percentage of the surface area of collagen fiber deposition. Penconazole treated group

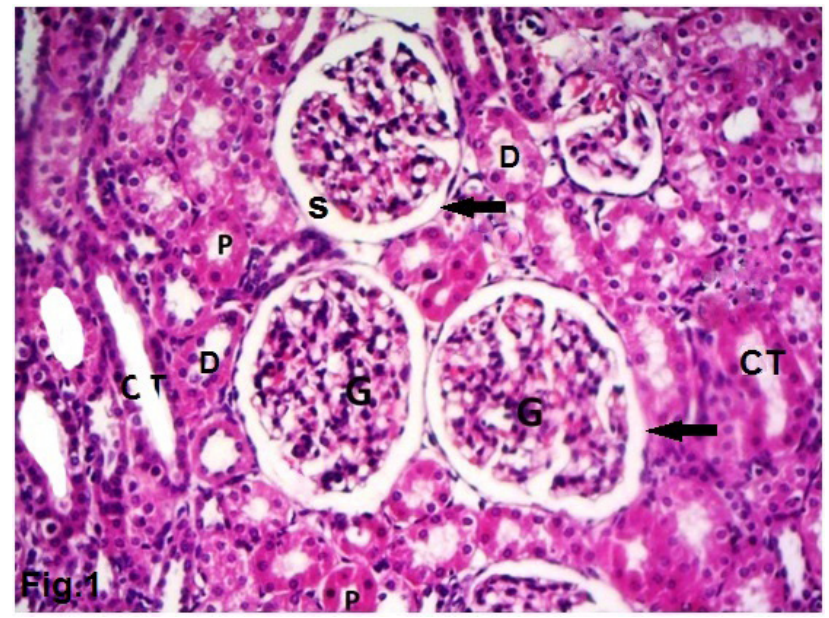

Fig . 1 : A photomicrograph of a section of renal cortex from the control group showing normal renal corpuscles (arrows) formed of glomerular tuft of capillaries $(\mathrm{G})$ and subcapsular space (S). PCT (P) shows narrow lumen and its lining cells have basal nuclei and deeply acidophilic cytoplasm. DCT (D) shows wide lumen and its lining cells have apical nuclei and less acidophilic cytoplasm. Notice: the presence of collecting tubules (CT).

(H\&E x200)

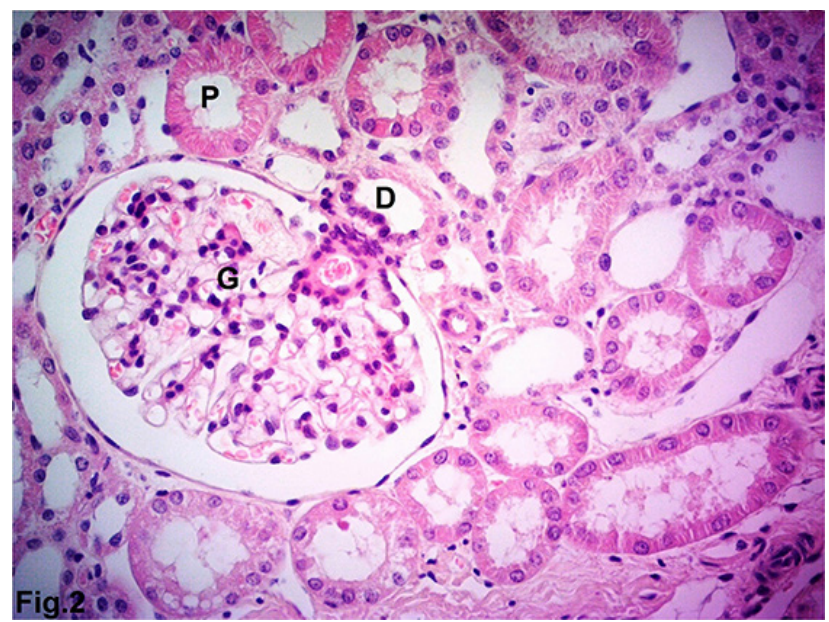

Fig. 2: A photomicrograph of a section of renal cortex from the control group showing renal corpuscles with glomerular capillaries $(G)$, proximal convoluted tubules $(\mathrm{P})$ and distal convoluted tubule with macula densa (D).

(H\&E x400) showed excessive deposition of collagen fiber, resulted in a highly significant increase $(p<0.001)$ in its surface area. Comparing with the treated group (group III), there was a significant decrease $(p<0.001)$ of collagen fiber deposition in the PEN $+N$. sativa group(Group IV) (Table 6, Histogram 6).

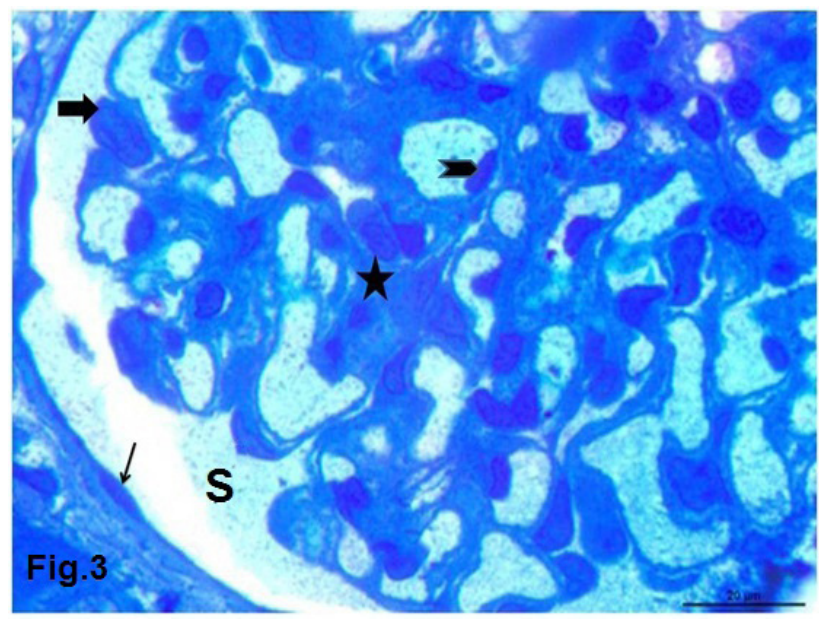

Fig 3: A photomicrograph of a semi thin section of control group showing renal corpuscle formed of a lobulated capillary tuft ( glomerulus) inside the Bowman's capsule. The latter is formed of outer parietal layer with simple squamous epithelium (thin arrow) and inner visceral layer lined with podocytes (thick arrow). Bowman's space (S) is seen in -between the parietal layer and visceral layer. The glomerular capillary is lined by endothelial cells ( arrow head) and separated by mesangial cells and an amorphousmatrix(star).

(Toluidine blue x1000)

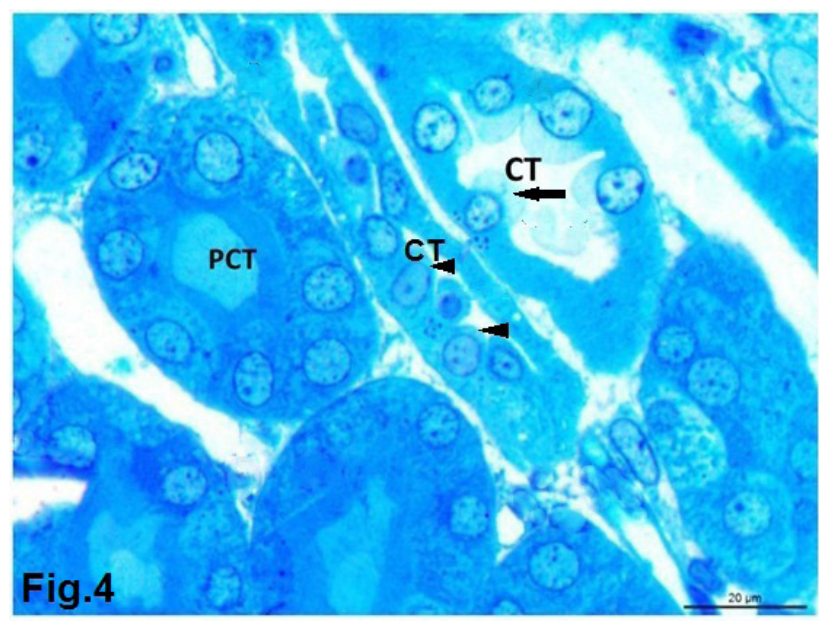

Fig 4: A photomicrograph of a semi thin section of control group showing PCT cells with large vesicular nuclei and well developed brush border. Notice: Presence of two cortical collecting tubules (CT) lined mainly by pale principal cells (arrow head) and darkly stained intercalated cells with apical cytoplasmic bleb ( arrow).

(Toluidine blue x1000) 


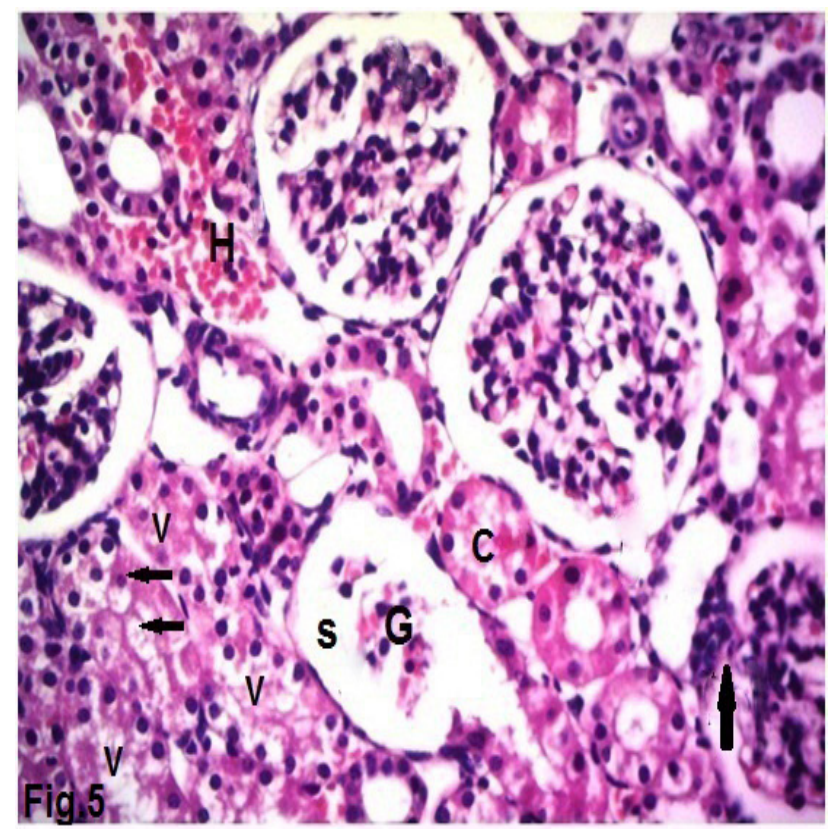

Fig .5 : A photomicrograph of a section of renal cortex from Penconazole - treated group showing renal corpuscle with glomerular atrophy $(\mathrm{G})$ and widening of the subcapsular space (S). Extraglomerular aggregation of darkly stained cells in some renal corpuscles (thick arrow) can be seen. Some tubules show vacuolation $(\mathrm{V})$ of its epithelial cells, other tubules show necroting epithelium (pyknosis and karyolysis) ( thin arrow) and acidophilic cast $(\mathrm{C})$ in their lumen. Notice: presence of hemorrhage $(\mathrm{H})$ in the interstitium.

(H\&E x400)

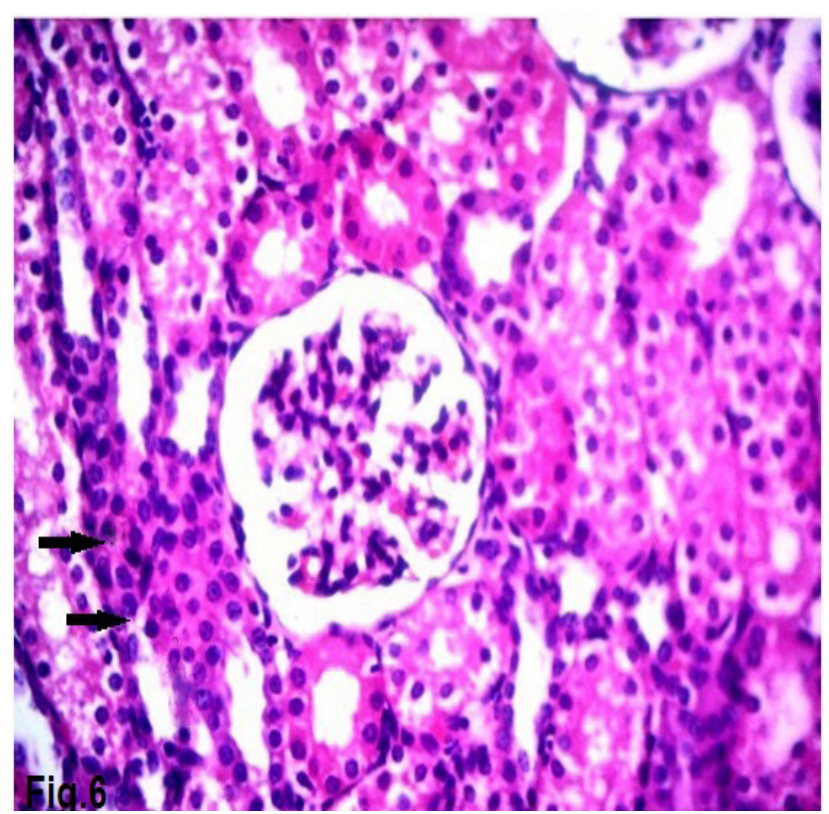

Fig. 6: A photomicrograph of a section of renal cortex from Penconazole - treated group showing hypercellularity of the interstituim of the renal cortex (arrow).

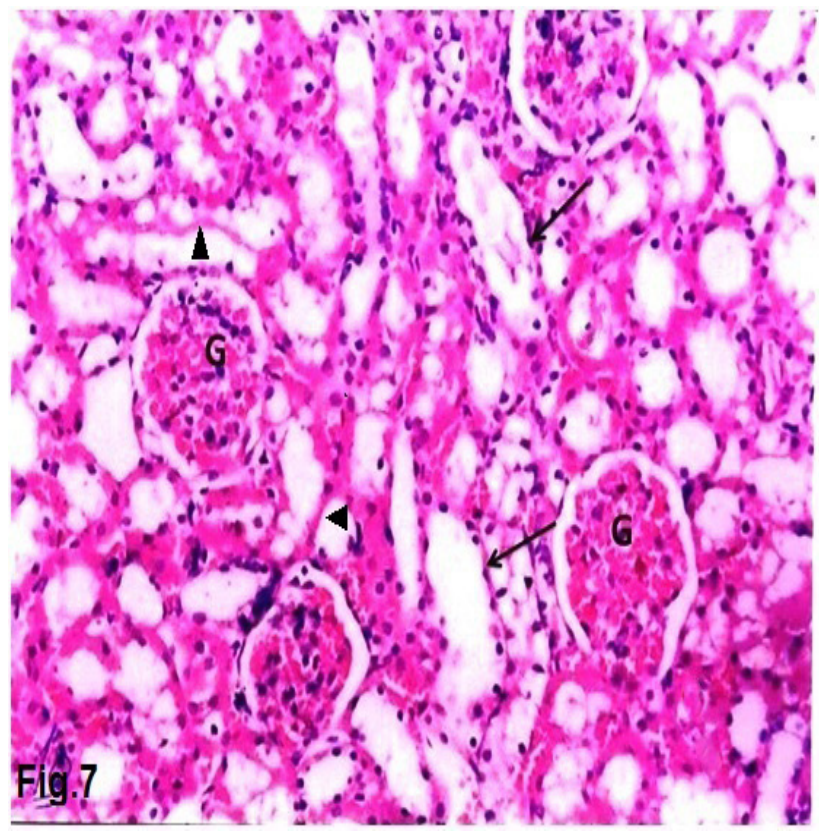

Fig.7: A photomicrograph of a section of renal cortex from Penconazole - treated group showing thin epithelial lining of some renal tubular cells with flattening of its nuclei (arrow). Epithelium of other tubules is denuded (arrow head). Congested glomerular capillaries $(G)$ are present.

(H\&E x200)

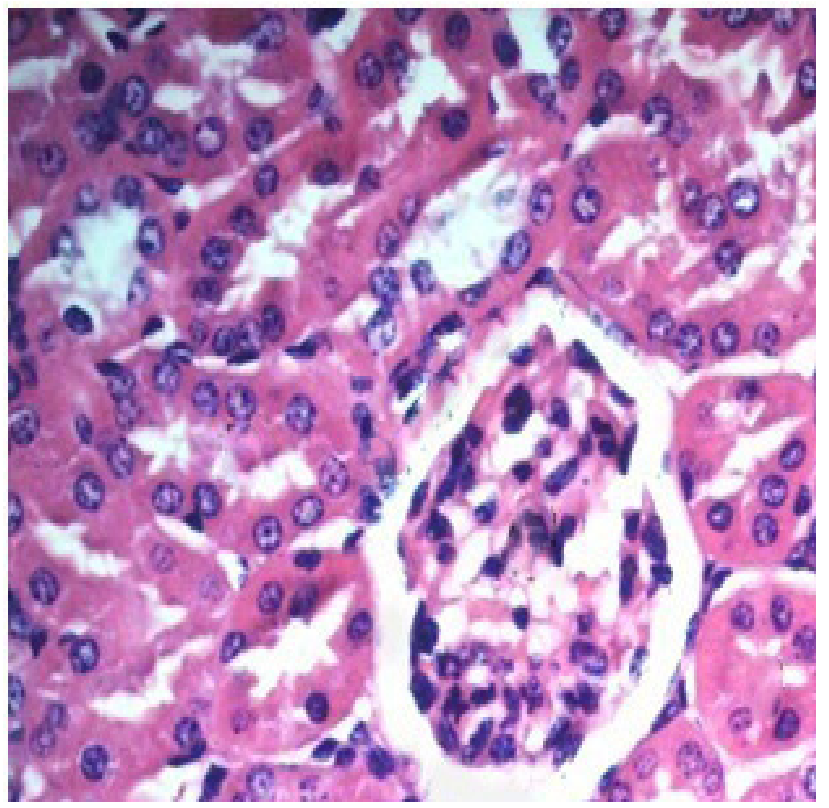

Fig .8: A photomicrograph of a section of renal cortex from Penconazole treated group showing cortical collecting tubule (CT) lined with many darkly stained intercalated cells, some of these cells showing apical cytoplasmic blebbing (arrow head) and others are binucleated (arrow).

(H\&E x200) 


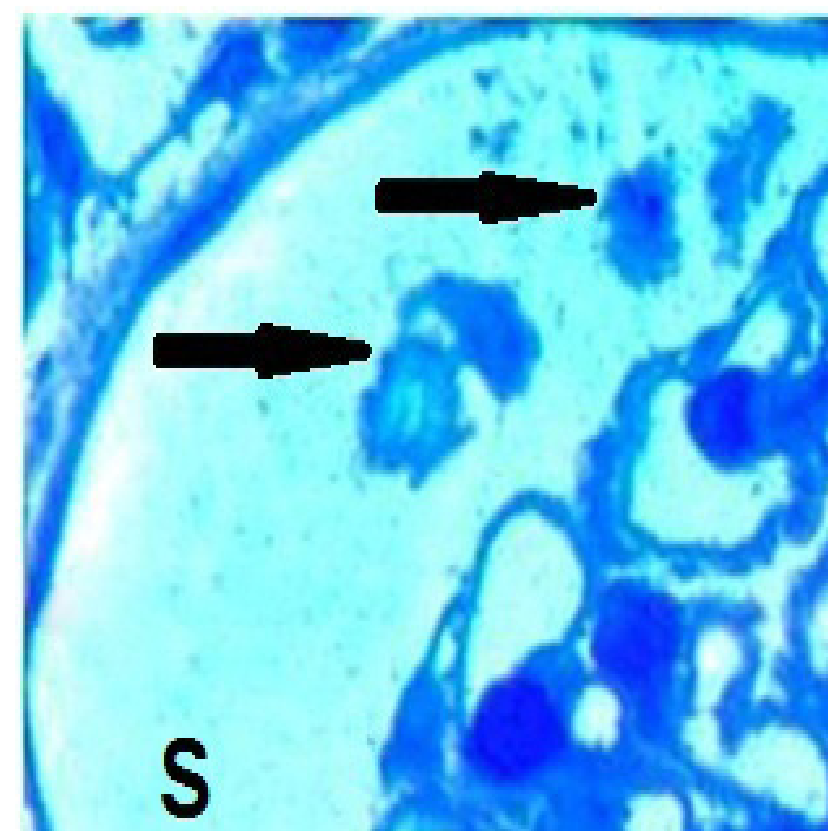

Fig .9: A photomicrograph of a semi thin section of Penconazole treated group showing renal corpuscle with atrophic glomerulus with widening of Bowman's space (S). Notice: Presence of degenerated podocytes inside the subcapsular space (arrow).

(Toluidine blue x1000)

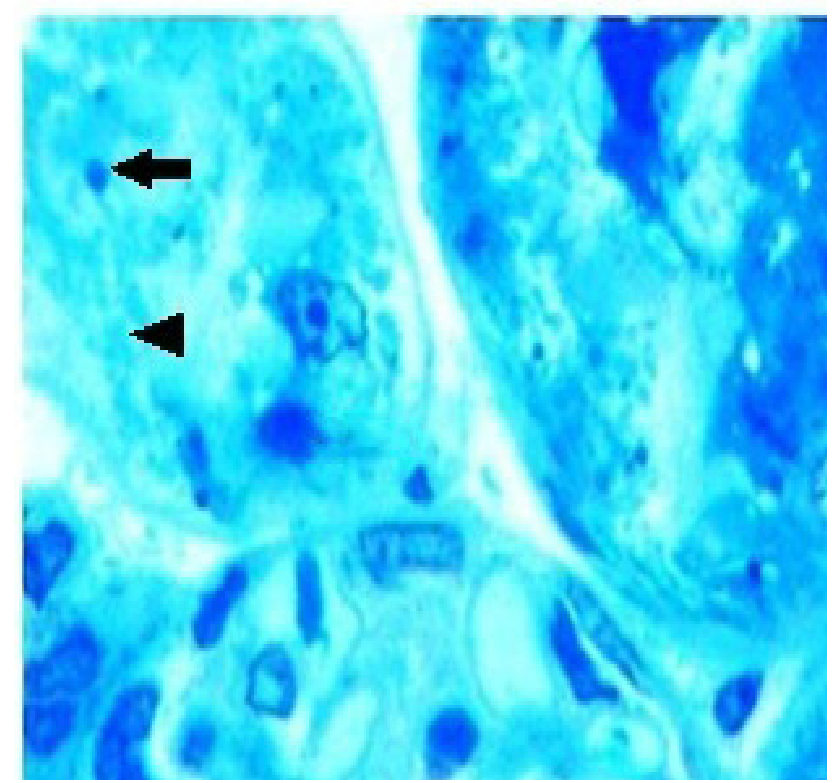

Fig. 10: A photomicrograph of a semithin section of Penconazole treated group showing hypercellularity of glomerular cells (G) and obliteration of the subcapsular space (S). Note some tubular cells lack the nuclei (arrow head), others show deeply stained nuclei (arrow).

(Toluidine blue x1000)

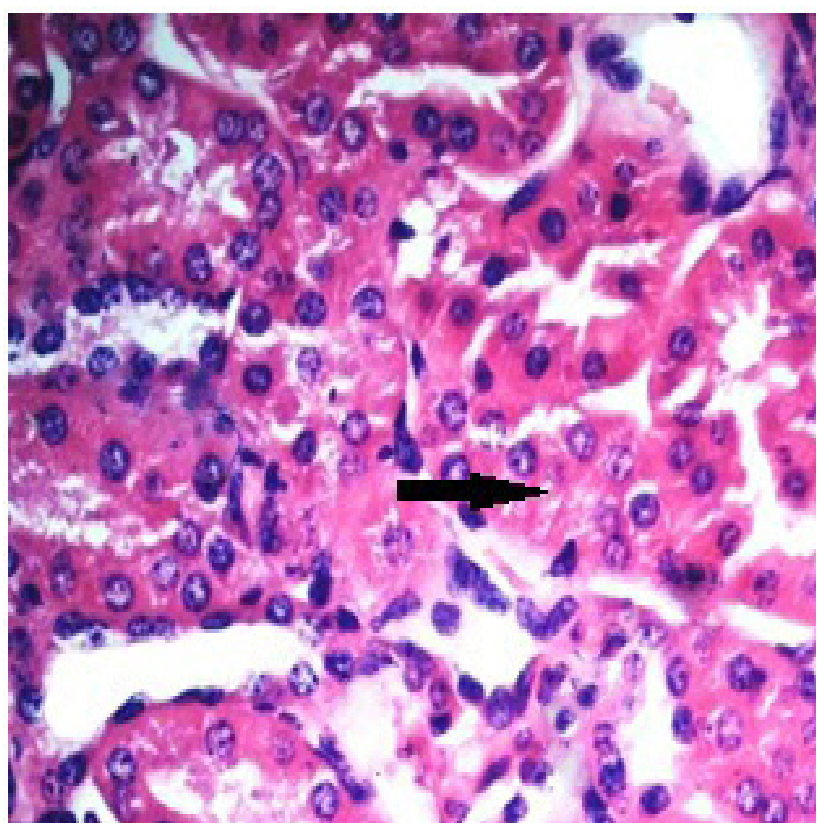

Fig .11: A photomicrograph of a section of renal cortex from Penconazole and Nigella sativa group showing normal glomeruli $(G)$.Some tubules are lined with epithelial cells, having dark nuclei with deeply acidophilic cytoplasm (P,D). Other tubules show epithelial cells with vesicular nuclei and pale cytoplasm (arrow head). Note some tubules lack lumen (arrows).

(H\&E x200)

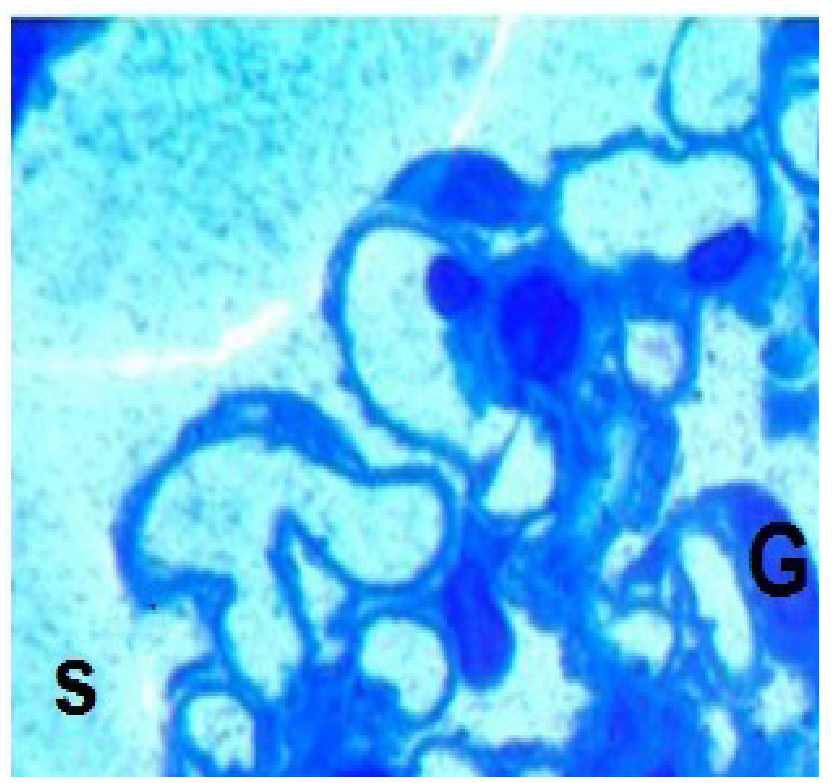

Fig .12: A photomicrograph of a semi thin section of Penconazole and Nigella sativagroup showing normal glomerular capillaries (G) and subcapsular space (S).

(Toluidine blue $\mathrm{x} 1000)$ 


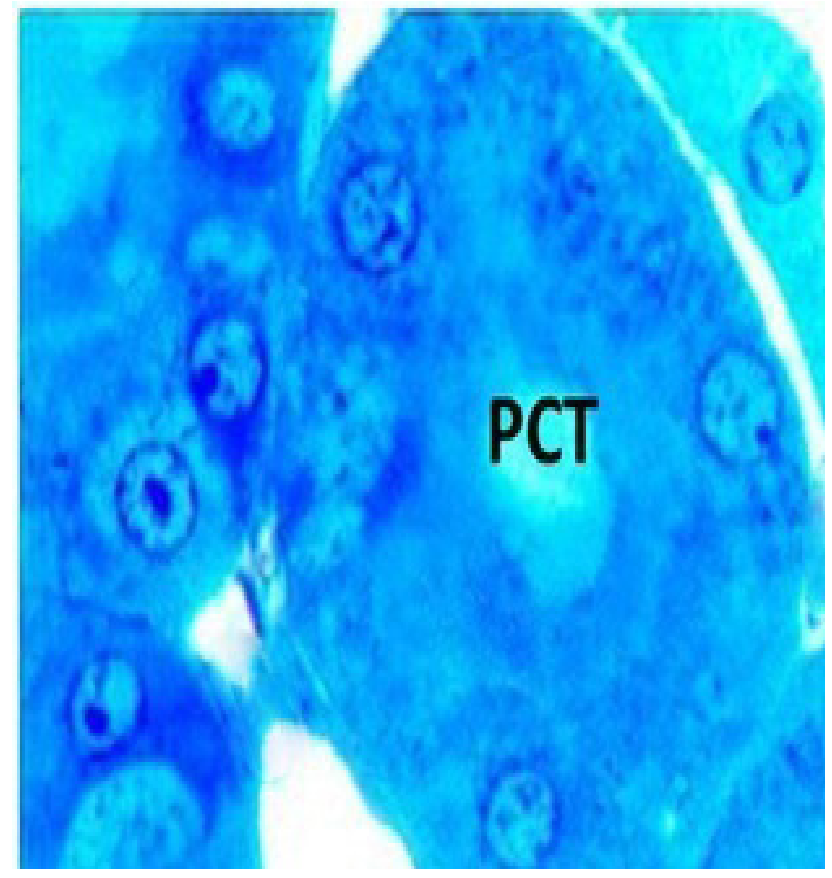

Fig .13: A photomicrograph of a semi thin section of Penconazole and Nigella sativa group showing PCT with less developed brush border. Notice presence of part of collecting tubule (CT) with intercalated cells (arrow).

(Toluidine blue x1000)

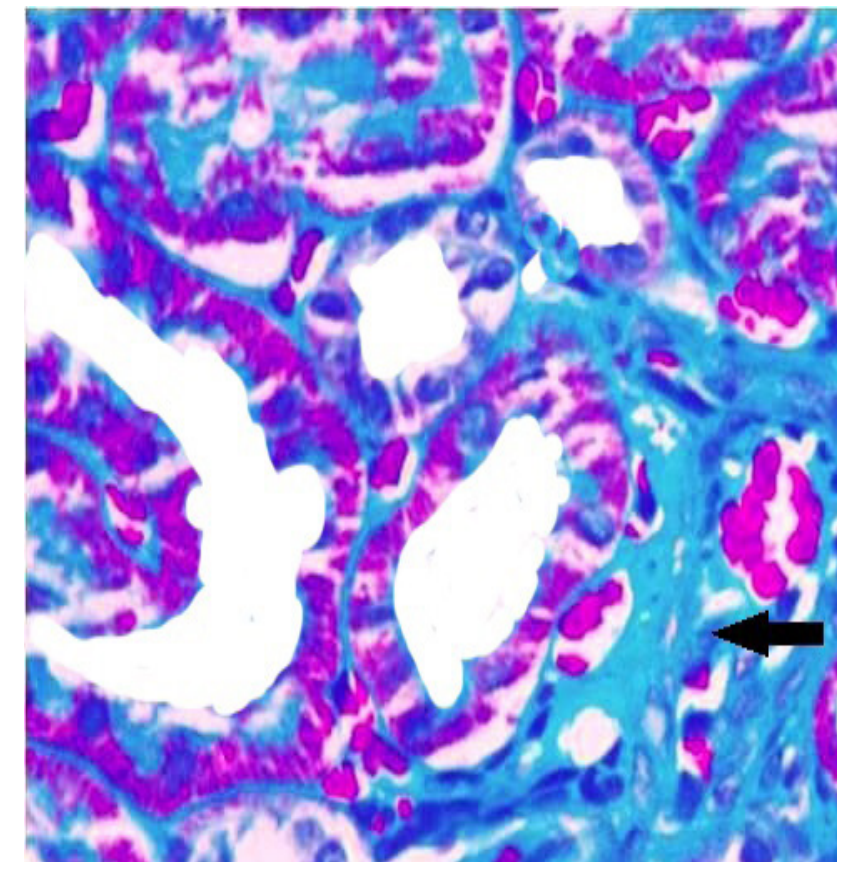

Fig.15: A photomicrograph of a section in renal cortex from PEN - treated group showing an increase of the collagen fibers in the interstitium and in between glomerular capillaries (arrows). (Masson Trichrome x 400)

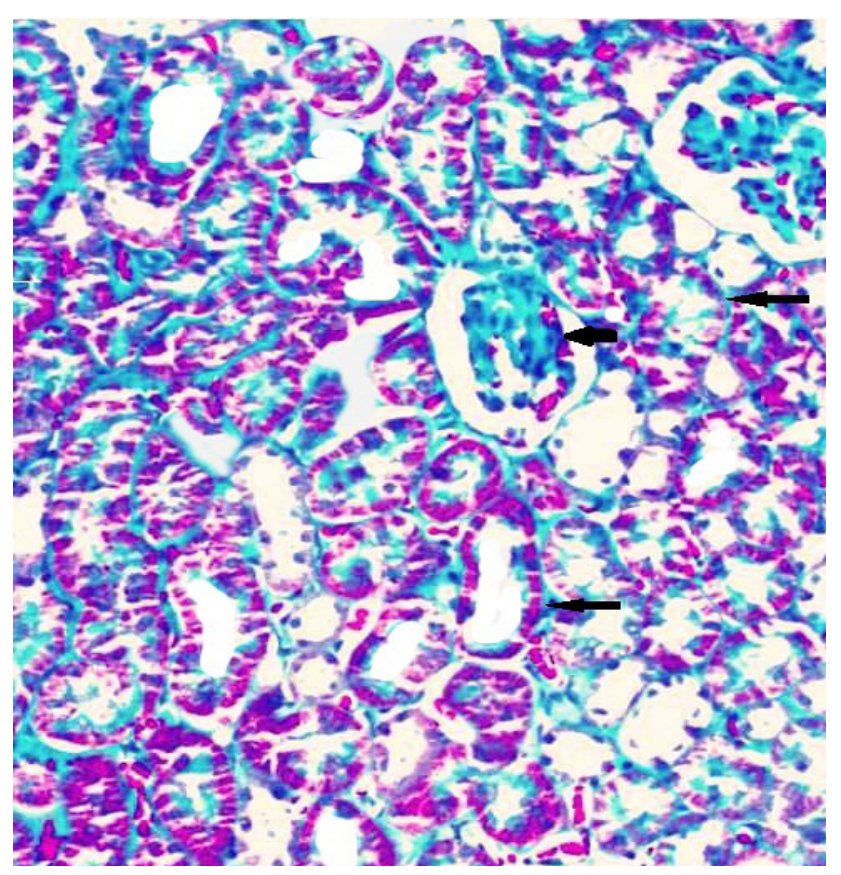

Fig.16: A photomicrograph of a section in renal cortex from $P E N+N$. sativa group showing minimal amount of collagen fibers around renal tubules and inside of the glomeruli (arrows).

(Masson Trichrome x 400) 
Khair et. al.,
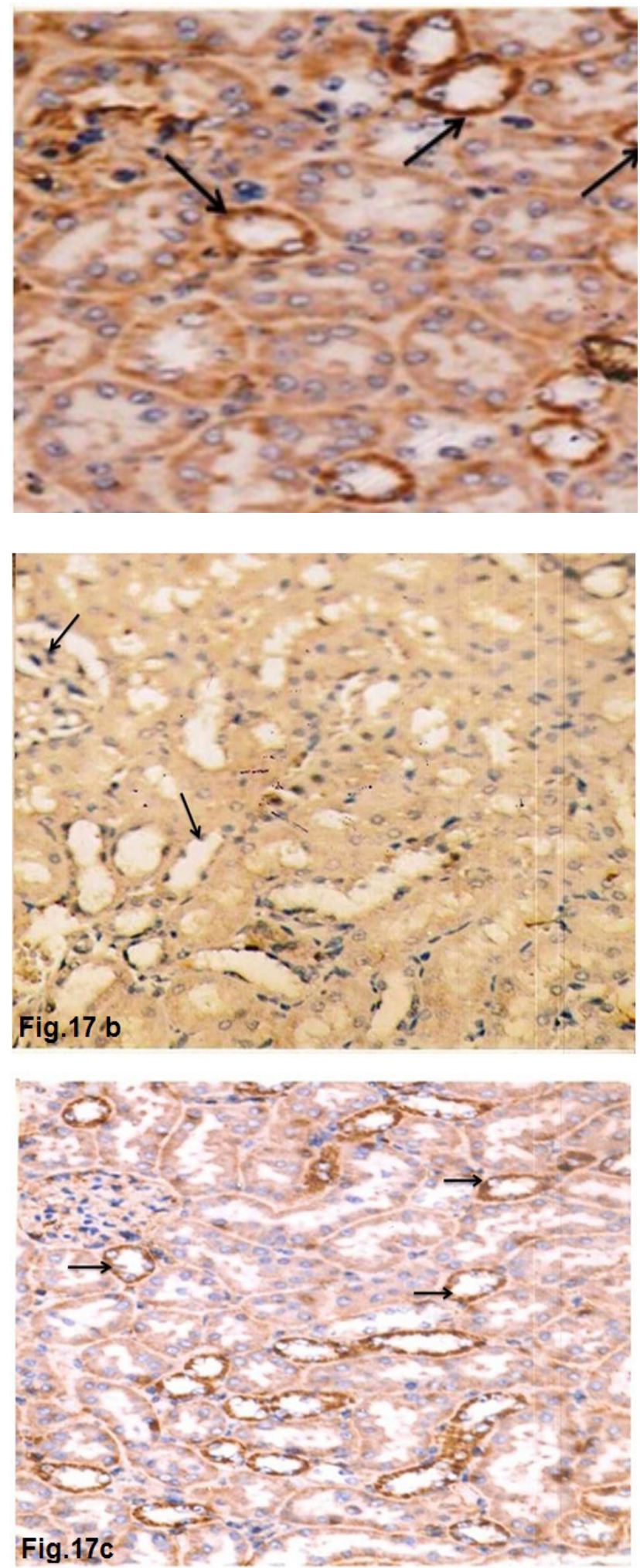

Fig 17 : Representative sections in rat renal cortex showing :

(a) Strong positive immunoreaction for Bcl-2 in renal tubules of control group (arrow)

(b) Negative immunoreaction for Bcl-2 in the basal portion of tubules and inside the glomeruli o fpenconazole - treated group (arrow)

(c) Moderate positive immunoreaction for $\mathrm{Bcl}-2$ in penconazole and Nigella sative treated group ( arrow).

(Bcl-2 x200 immunostaining)
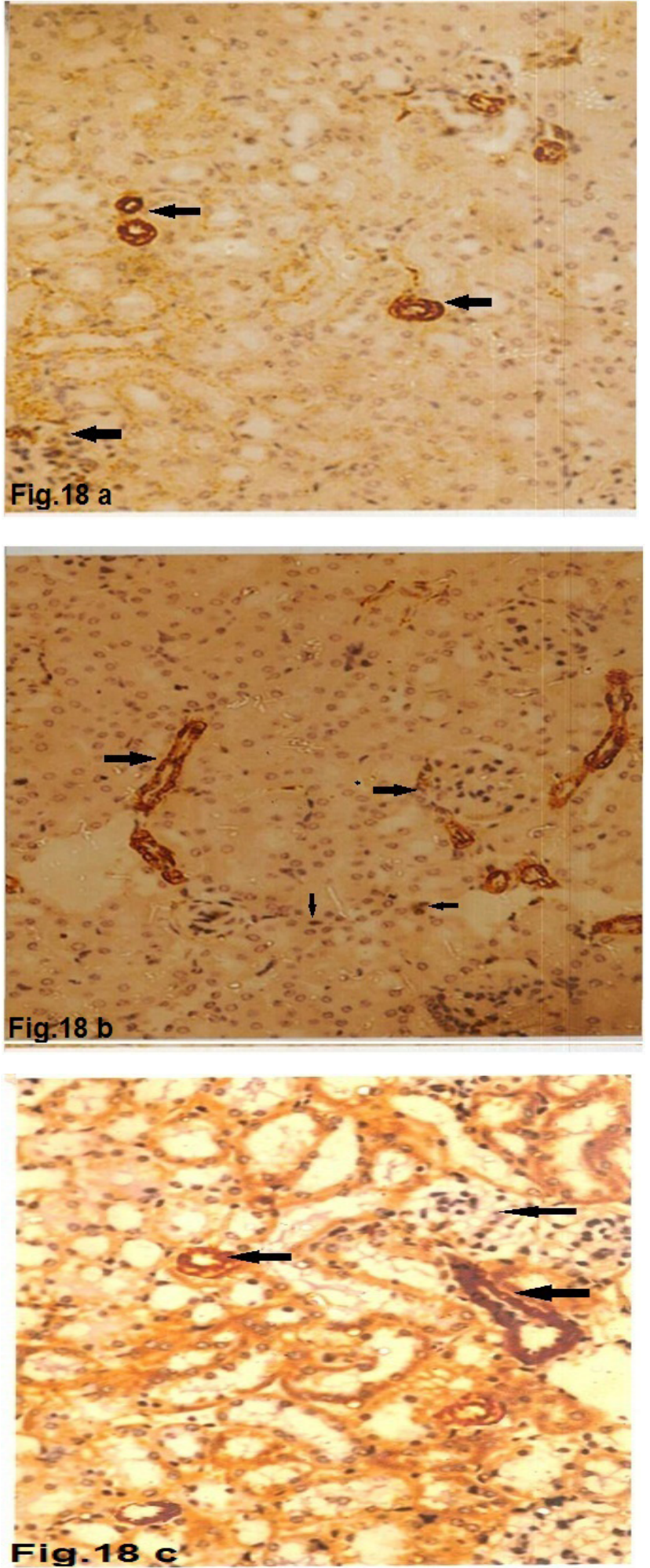

Fig 18 : Representative sections in rat renal cortex showing :

(a) Moderate positive immune-reaction of $\alpha$ SMA in the blood vessels and in the glomeruli of the renal corpuscles of control rat (arrow)

(b) Strong positive immune reaction of $\alpha$ SMA in interstitial fibroblasts, the wall of blood vessels and in the renal glomeruli of penconazole treated group (arrows)

(c) Moderate positive immune reaction of $\alpha$ SMA in the blood vessels (arrow) and negative reaction in renal glomeruli (head arrow).

( $\alpha$ SMA x200 immunostaining) 


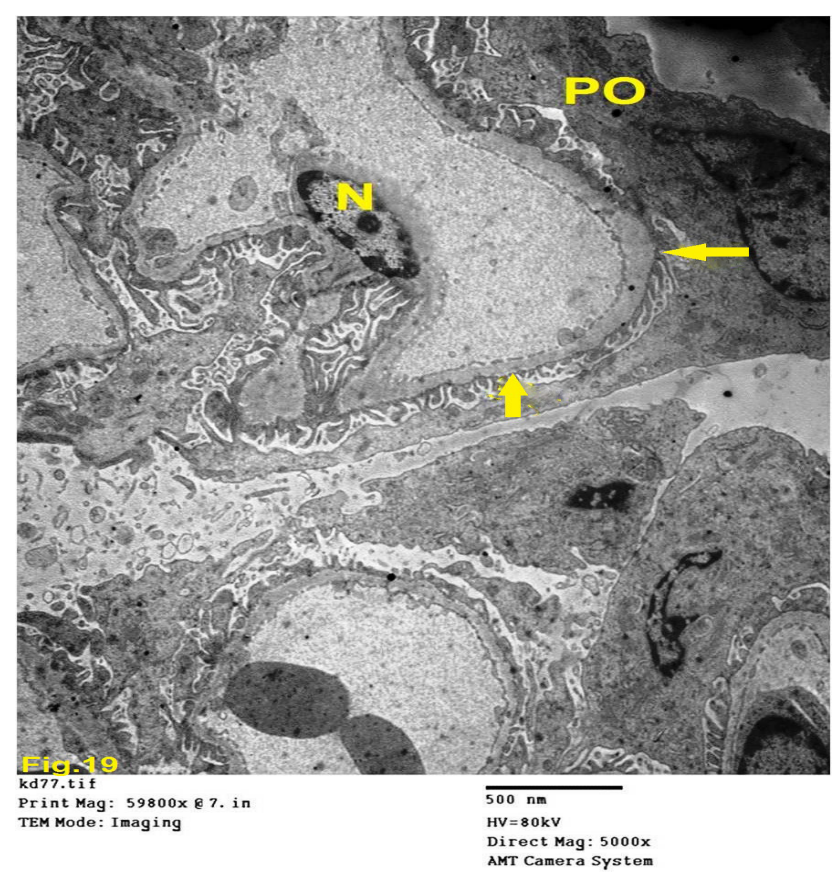

Fig 19: Electron micrograph of the renal cortex of control group showing Podocyte with euchromatic nucleus, having primary and secondary processes (PO), wrapped the glomerular capillaries. The glomerular basement membrane is intact and uniform (arrow), the capillary endothelial cells showing euchromatic nucleus $(\mathrm{N})$.

(TEM x 5000)

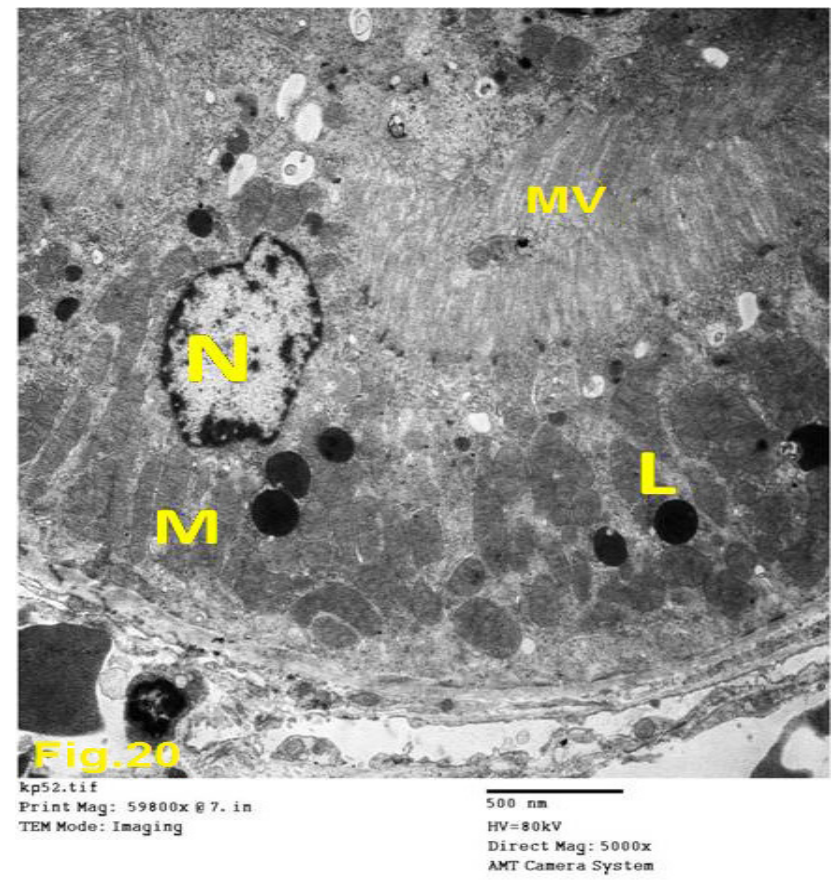

Fig.20: Electron micrograph of the renal cortex of control group showing Part of PCT cell showing euchromatic nucleus (N), apical microvilli (MV), electron dense lysosomes (L) and basally located numerous longitudinally arranged mitochondria(M).

(TEM x 5000)

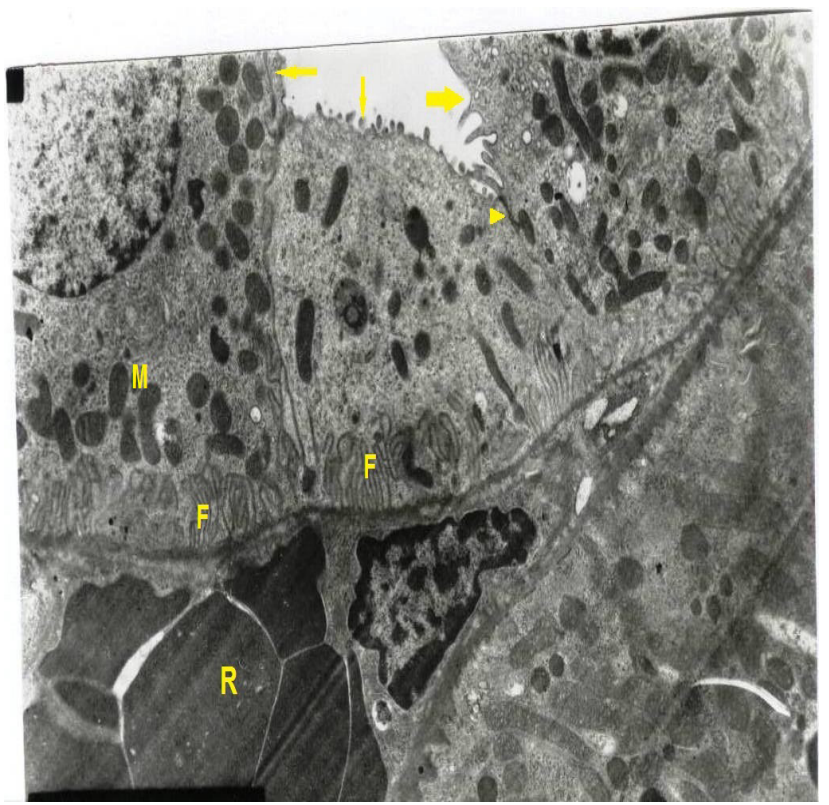

Fig.21: Electron micrograph of the renal cortex of control group showing part of cortical collecting duct showing two principal cells with electron lucent cytoplasm (thin arrow), small mitochondria (M) and basal infoldings (F). One intercalated cell with electron dense cytoplasm, scattered mitochondria , apical microvilli and numerous apical vesicles (thick arrow).Tight junction between the principal cell and the intercalated cell (head arrow) can be seen. Note blood capillaries (R) in the interstitium.

(TEM x 5000)

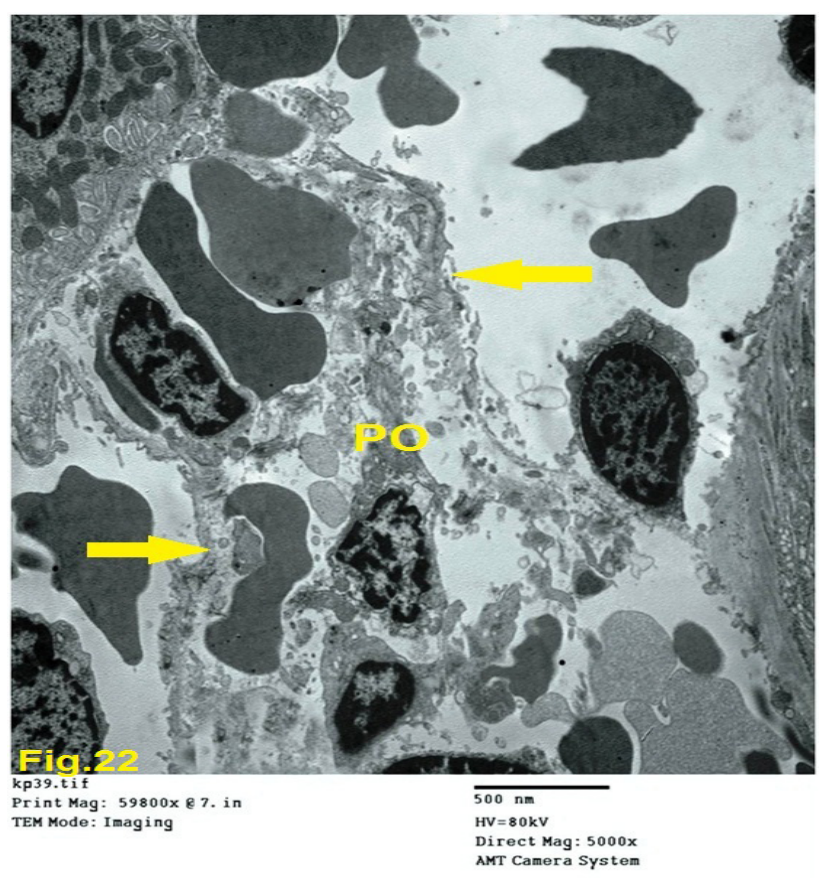

Fig.22: Electron micrographof the renal cortex of Penconazole treated rat showing disruption of the wall of blood capillaries (arrow) and detachment of podocytes with disruption of its processes (PO) (TEM $\times 5000)$ 


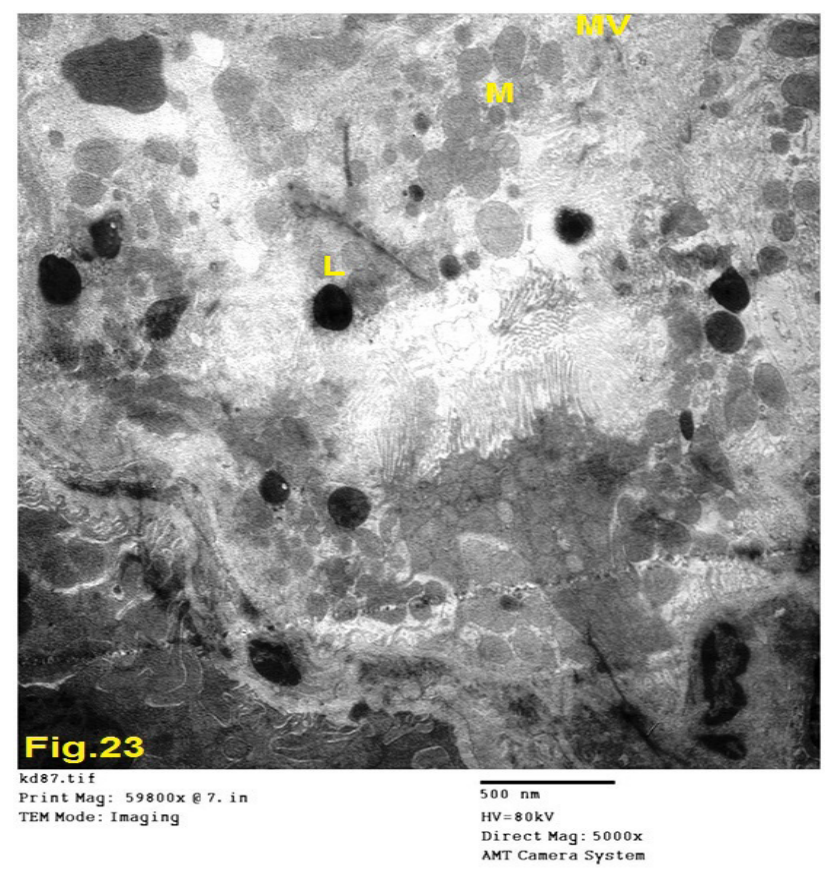

Fig.23: Electron micrograph of the renal cortex of Penconazole treated rat showing PCT cell with destruction of its microvilli (MV), few mitochondria (M) and numerous lysosomes (L).

(TEM x 5000)

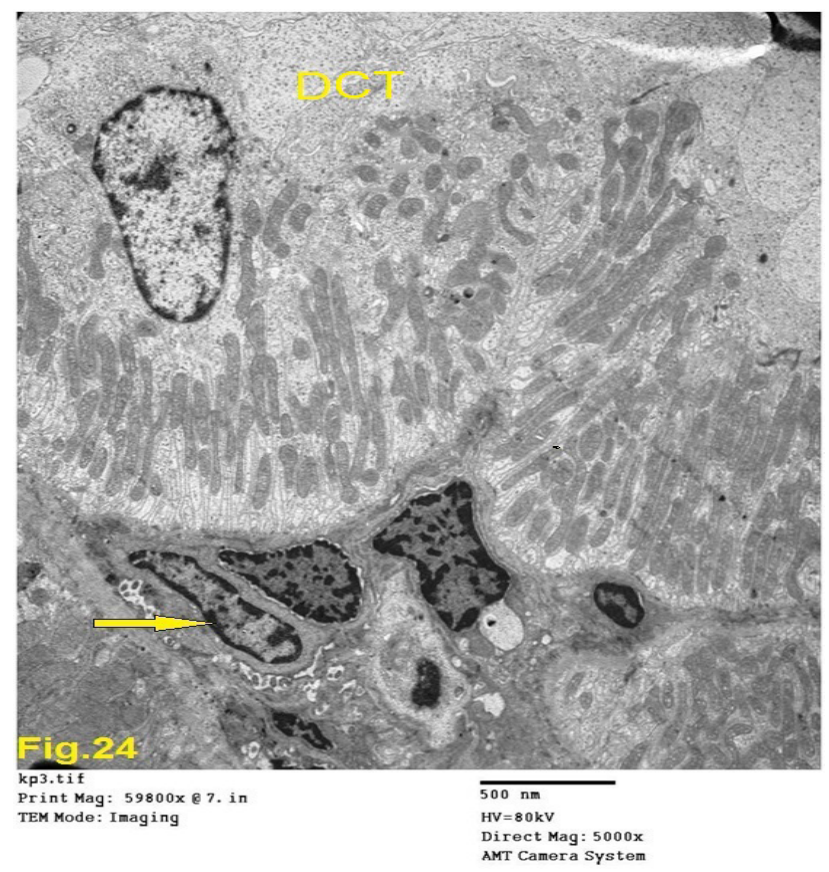

Fig.24: Electron micrograph of the renal cortex of Penconazole treated rat showing part of normally appearing DCT cells . Note: hypercellularity of the interstitium (arrow).

(TEM x 5000)

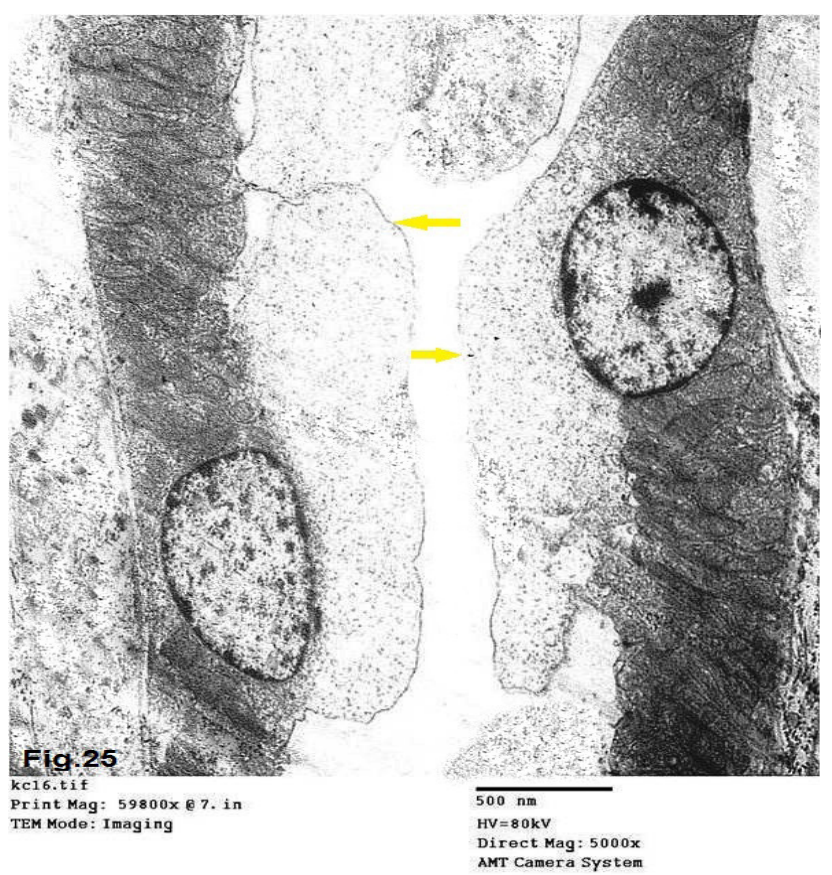

Fig.25: Electron micrograph of the renal cortex of Penconazole treated rat showing part of collecting duct cell having numerous electron dense intercalated cells with increase in apical organelle - free cytoplasmic blebbing (arrow).

(TEM x 5000)

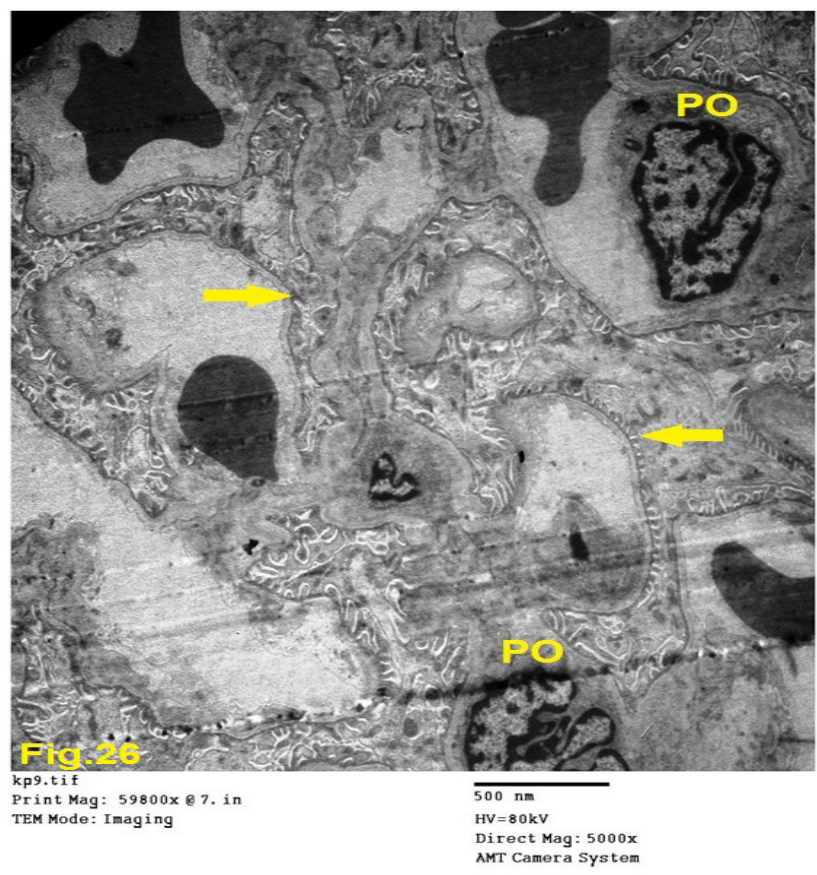

Fig.26: Electron micrograph of the renal cortex of Penconazole and Nigella sativa treated group showing intact vesicular nucleus of podocyte (PO) and nearly intact glomerular basement membrane (arrow)

(TEM x 5000) 


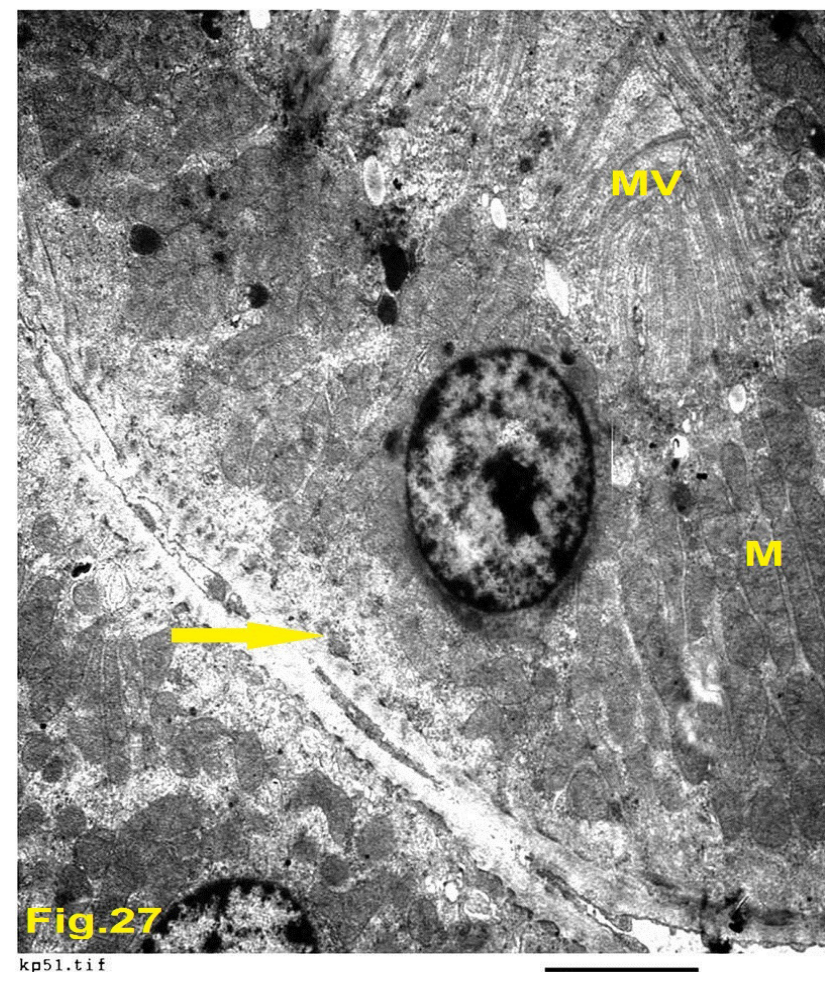

Fig.27: Electron micrographof the renal cortex of Penconazole and Nigella sativa treated group showing PCT cell with normally appearing microvilli (M) and mitochondria (M). some areas of disrupted basement membrane and basal membrane infoldings are also seen (arrow).

(TEM x 5000)

Table (1): Change in body and kidney weight in grams in different animal groups

\begin{tabular}{lcc}
\hline \multicolumn{1}{c}{ Group } & Body weight $\mathrm{x}^{-} \pm \mathrm{SD}$ & $\begin{array}{c}\text { Kidney weight } \\
\mathrm{x}^{-} \pm \mathrm{SD}\end{array}$ \\
\hline Control & $261.00 \pm 6.81$ & $1.68+-0.10$ \\
Nigella sativa & $267.67 \pm 9.18$ & $1.67 \pm 0.17$ \\
PEN & $248.67 \pm 8.48^{*}$ & $1.66 \pm 0.15$ \\
PEN + N. sativa & $256.43 \pm 4.66^{*}$ & $1.64 \pm 0.06$ \\
F & 14.434 & 0.57 \\
$P$ value & 0.001 & 0.633 \\
\hline
\end{tabular}

(*) Significant at $P<0.05$ compared with control group

( $\bullet$ Significant from the treated group $(p<0.05)$

$\mathrm{x}^{-}=$The mean value. $\mathrm{SD}=$ the standard deviation

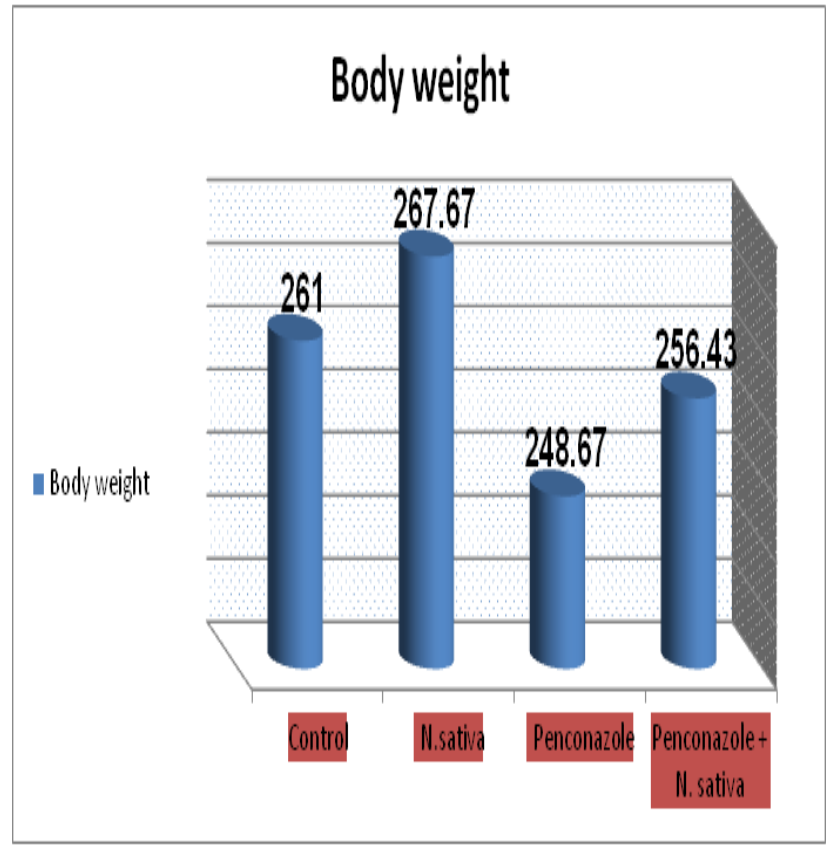

Histogram (1a):Change in the body weight in grams in different animal groups.

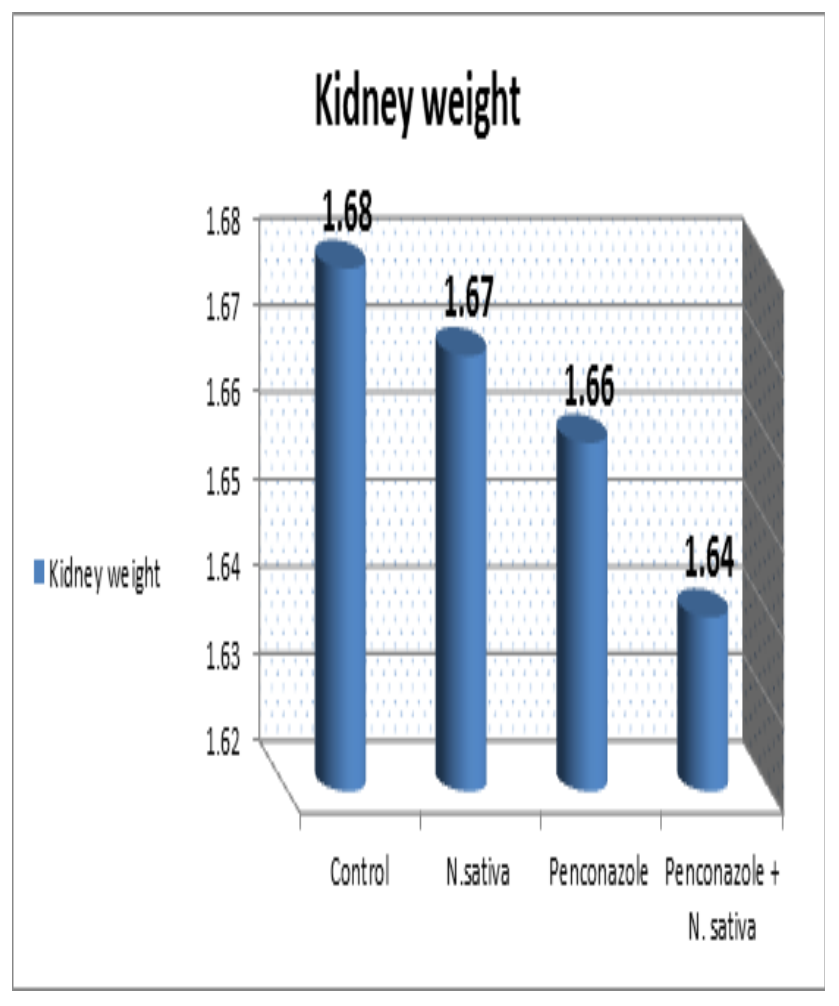

Histogram (1b): Change in kidney weight in grams in different animal groups. 
Table (2): Meanplasma urea \& creatinine concentrations in all groups ( $\mathrm{mmol} / \mathrm{L} \& \mu \mathrm{mol} / \mathrm{L}$ respectively)

\begin{tabular}{|c|c|c|}
\hline Group & $\begin{array}{c}\text { Plasma urea } \\
(\mathrm{mmol} / \mathrm{L}) \\
\mathrm{x}^{-} \pm \mathrm{SD}\end{array}$ & $\begin{array}{c}\text { Plasma creatinine }(\mu \mathrm{mol} / \mathrm{L}) \\
\qquad \mathrm{x}^{-} \pm \mathrm{SD}\end{array}$ \\
\hline Control & $29.80 \pm 6.05$ & $0.4590 \pm 0.1363$ \\
\hline N. sativa & $31.10 \pm 4.28$ & $0.5150 \pm 0.1112$ \\
\hline PEN & $64.30^{* *} \pm 12.98$ & $1.3960^{* *} \pm 0.5091$ \\
\hline PEN +N.sativa & $38.00^{* *} \pm 3.74$ & $0.7380^{* \star} \pm 0.2011$ \\
\hline
\end{tabular}

$\mathrm{x}^{-}=$the mean value. $\mathrm{SD}=$ the standard deviation. $\mathrm{Mmol} / \mathrm{L}=$ millimoles $/$ Liter.

$\mu \mathrm{mol} / \mathrm{L}=$ micromoles/Liter.

** Significant from the control group $(p<0.001)$.

$\leftrightarrow$ Significant from the treated group (IV) $(p<0.001)$.

\section{Plasma urea}

- Plasma urea
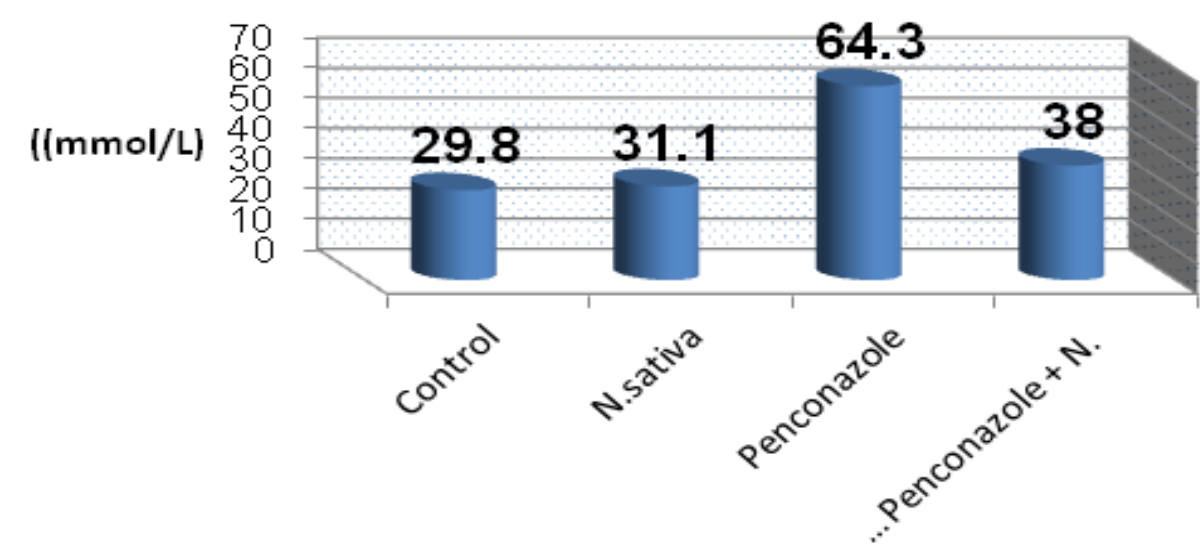

Histogram (2a): Mean plasma urea concentrations in all groups (mmol/ L)

\section{Plasma creatinine ( $\mu \mathrm{mol} / \mathrm{L}$ )}

- (Plasma creatinine ( $\mu \mathrm{mol} / \mathrm{L}$

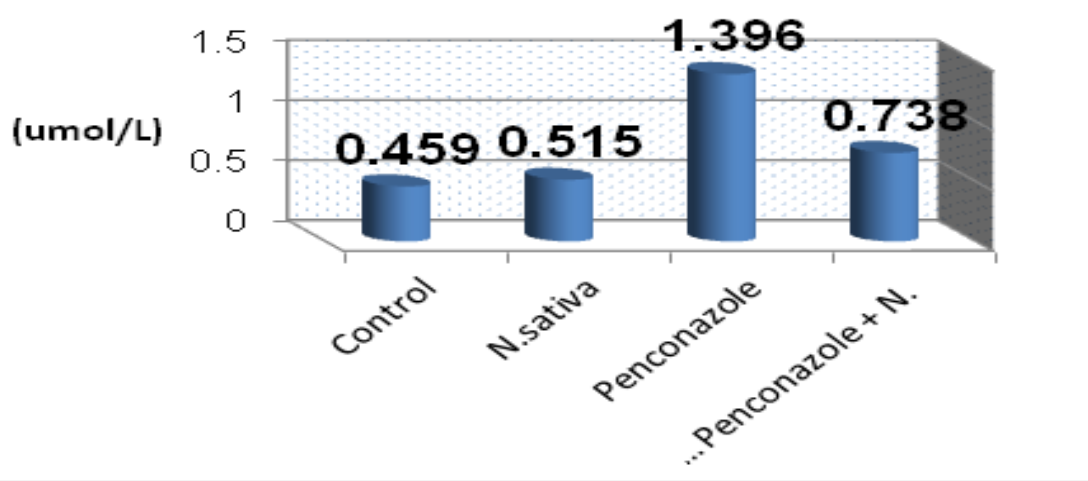

Histogram (2b): Mean plasma creatinine concentrations in all group $(\mu \mathrm{mol} / \mathrm{L})$ 
Table (3): Morphometric analysis of optical density of Bcl-2 and $\alpha$-smooth muscle actin performed on rat kidney . Data are presented as mean \pm SEM on 10 animals per group.

\begin{tabular}{|c|c|c|}
\hline Group & $\mathrm{Bcl} 2$ & $\alpha$-SMA \\
\hline Control & $107.11 \pm 0.32$ & $66.11 \pm 0.31$ \\
\hline PEN & $79.37 \pm 0.3^{*}$ & $97.0 \pm 0.40^{*}$ \\
\hline PEN +N.sativa & $92.32 \pm 0.44$ & $76.280 \pm .06$ \\
\hline
\end{tabular}

* Significant at $P<0.05$

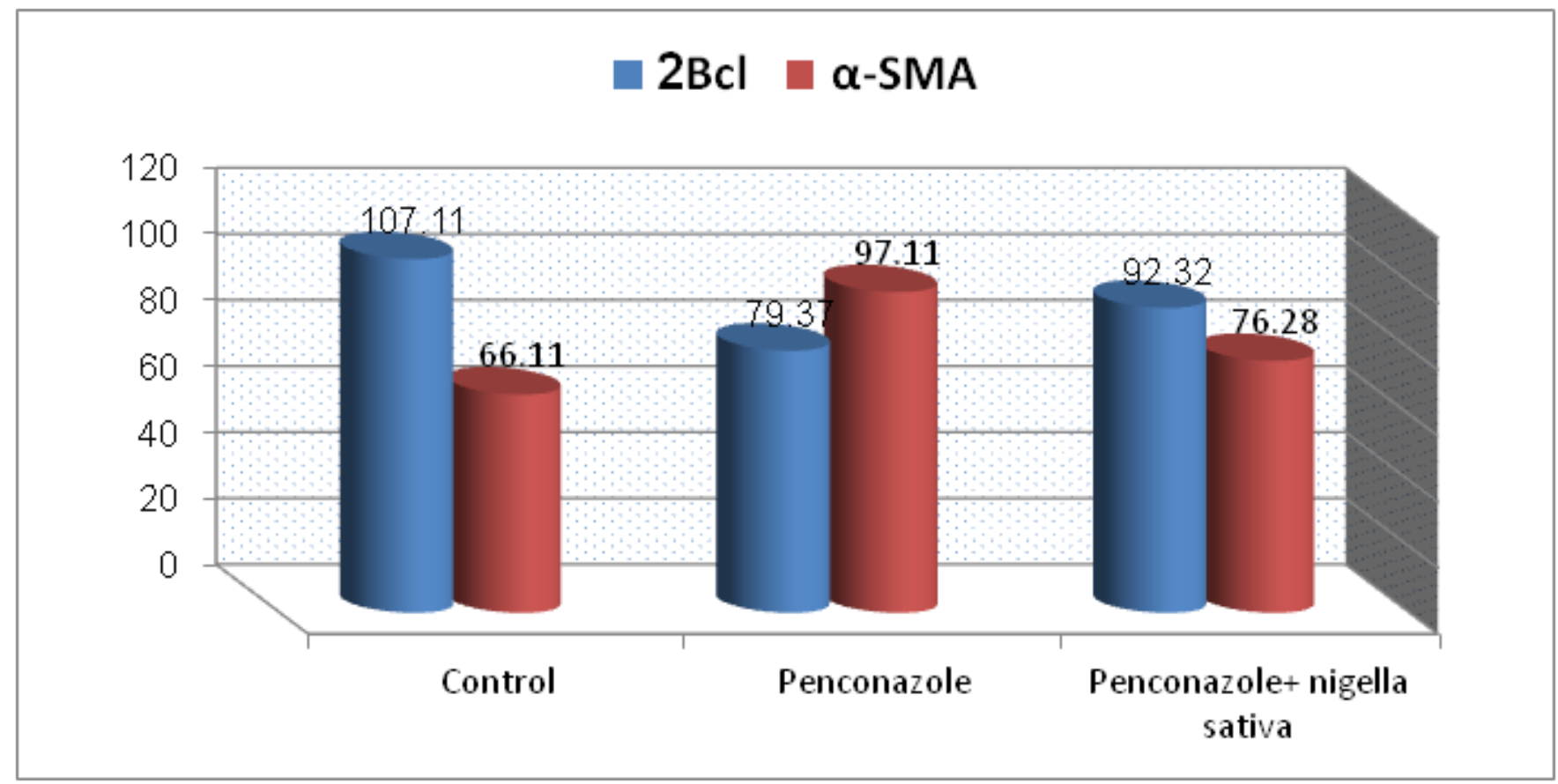

Histogram (3): Morphometric analysis of optical density of BCL2 and $\alpha$-smooth muscle actin performed on rat kidney.

Table 4: Effect of different treatments on MDA, SOD and CAT in renal tissue of all groups of rats

\begin{tabular}{lccc}
\hline \multicolumn{1}{c}{ Group } & $\begin{array}{c}\text { MDA(nmol/mg } \\
\text { protein) } \mathrm{x}^{-} \pm \mathrm{SD}\end{array}$ & $\mathrm{SOD}\left(\mathrm{U} / \mathrm{mg}\right.$ protein) $\mathrm{x}^{-} \pm \mathrm{SD}$ & CAT(U/mg protein) $\mathrm{x}^{-} \pm \mathrm{SD}$ \\
\hline Control & $15.5 \pm 1.5$ & $220 \pm 18.6$ & $530 \pm 20.4$ \\
N. sativa & $16.3 \pm 1.8$ & $222 \pm 20.5$ & $541 \pm 19.5$ \\
PEN & $29.4 \pm 2.2^{*}$ & $165 \pm 10.6^{*}$ & $258 \pm 21.5^{*}$ \\
PEN +N.sativa & $20.8 \pm 1.3$ & $200 \pm 12.5$ & $410 \pm 16.5$ \\
\hline$\left.{ }^{*}\right)$ Significant at $P<0.05$ compared with control group & & \\
$\mathrm{x}^{-}=$the mean value. $\mathrm{SD}=$ the standard deviation. & & \\
\end{tabular}


Khair et. al.,

\section{MDA(nmol/mg protein )}

(MDA(nmol/mg protein

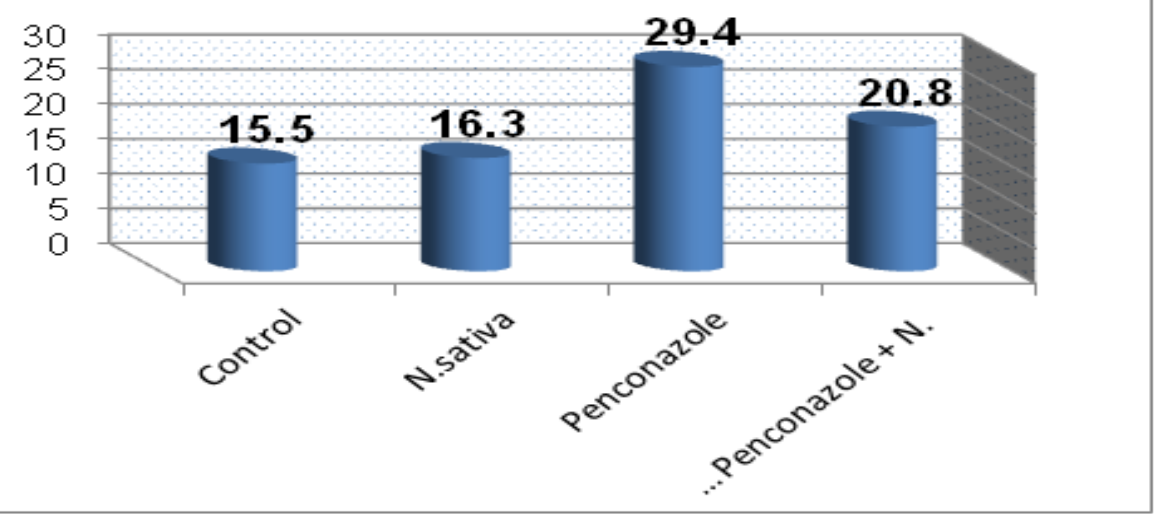

Histogram 4a: Effect of different treatments on MDA level in renal tissue of all groups

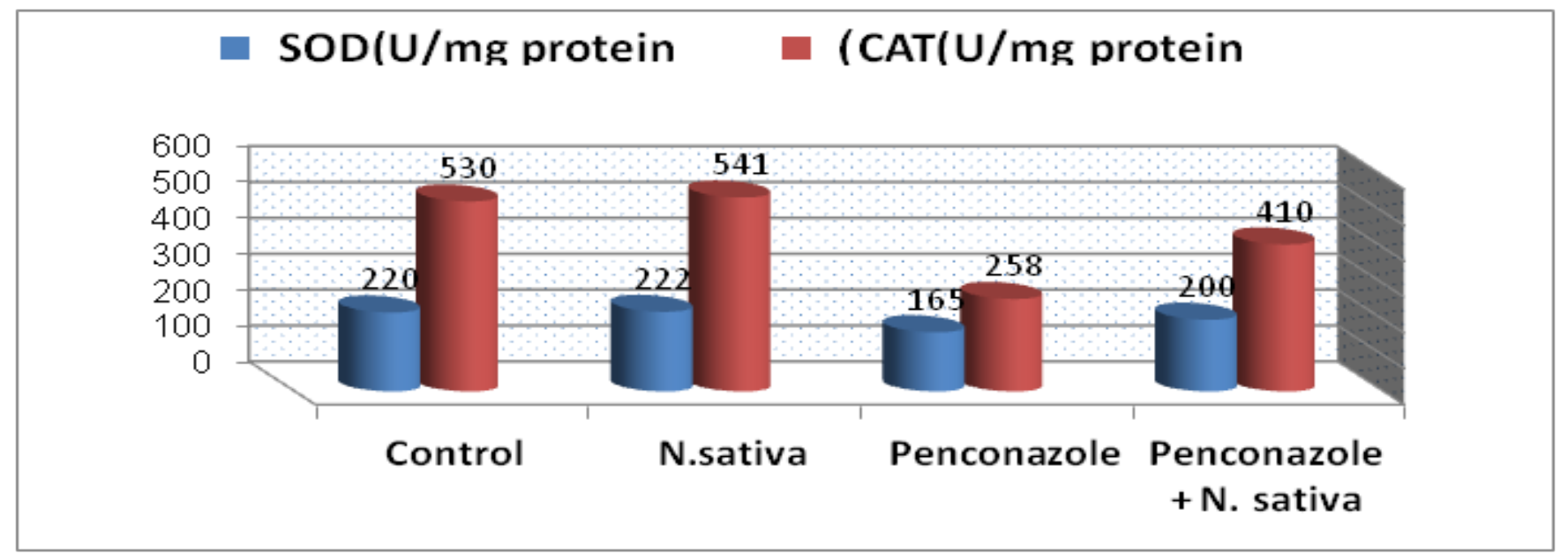

Histogram 4b: Effect of different treatments on SOD and CAT levels in renal tissue of all groups

Table 5: Renal corpuscle measurements (in $\mu \mathrm{m}$ )

\begin{tabular}{|c|c|c|}
\hline Group & $\begin{array}{l}\text { Diameter of the renal corpuscle }(\mu \mathrm{m}) \\
\qquad \mathrm{x}^{-} \pm \mathrm{SD}\end{array}$ & $\begin{array}{l}\text { Diameter of the Bowman's space }(\mu \mathrm{m}) \\
\qquad \mathrm{x}^{-} \pm \mathrm{SD}\end{array}$ \\
\hline Control & $123.060 \pm 14.176$ & $28.8 \pm 0.667$ \\
\hline N. sativa & $124.660 \pm 14.970$ & $29.7 \pm 0.941$ \\
\hline PEN & $90.140^{*} \pm 12.034$ & $50.38^{* *} \pm 0.719$ \\
\hline PEN +N.sativa & $107.520 \pm 16.648$ & $21.86 \pm 0.581$ \\
\hline
\end{tabular}

$\mathrm{x}^{-}=$the mean value. $\mathrm{SD}=$ the standard deviation.

$\mu \mathrm{m}=$ micrometer.

$*, * *$ Significant from the control group $(p<0.05 \&<0.001$ respectively) 


\section{Diameter of the renal corpuscle}

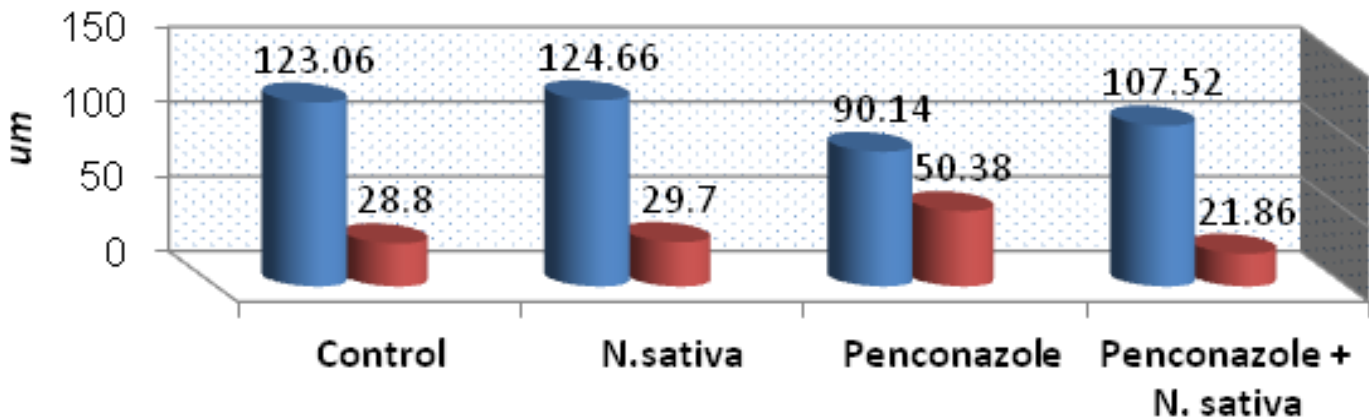

Histogram 5: Renal corpuscle measurements (in $\mu \mathrm{m}$ ) in all groups

Table 6: Mean surface area percentage of collagen fiber deposition

Control

N.sativa

PEN

$\mathrm{PEN}+\mathrm{N}$. sativa
$10.374 \pm 1.3682$

$10.4060 \pm 1.7260$

$27.1120^{* *} \pm 5.9670$

$14.8140 \pm 4.9415^{* \bullet}$

$\mathrm{x}^{-}=$the mean value. $\mathrm{SD}=$ the standard deviation.

$\%=$ percentage.

** Significant increase from the control group $(p<0.001)$.

$\leftrightarrow$ Significant from (group III) $(p<0.001)$

\section{$\%$ Collagen surface area}

$\%$ Collagen surface area
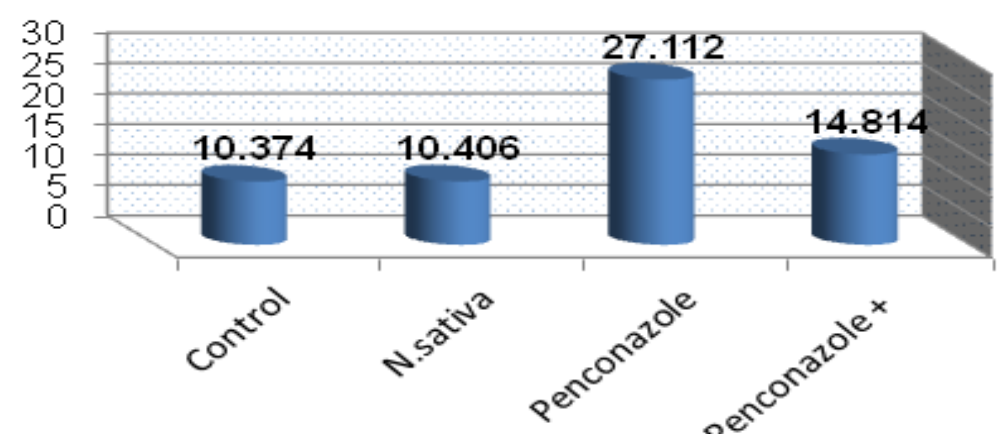

Histogram 6: Mean surface area percentage of collagen fiber deposition in all groups 


\section{DISCUSSION}

In this current study, penconazole administration resulted in nephrotoxicity, affecting the glomeruli, kidney tubules and the interstitium. In our present work, penconazole had significant decrease on body weight. Similar results were detected by ${ }^{[24]}$ who observed similar toxicological effects of propiconazole on mice. Also, ${ }^{[25]}$ declared that penconazole toxicity led to loss of appetite. This was in accordance with ${ }^{[2]}$ who attributed loss of appetite to the circulating uremic toxins produced by penconazole toxicity.

Light microscopic study of penconazole treated animals in group III revealed atrophied glomeruli with widening of the subcapsular space. Hypercelluarity of glomerular cells and congested glomerular capillaries in some renal corpuscles were also detected. These findings were matched with the previous results of ${ }^{[27]}$ in Diazinon treated rats. This was also coincident with ${ }^{[28]}$ who observed that in metiram- induced nephrotoxicity, the glomeruli were atrophied and shrunken with subsequent widening of the Bowman's space. In addition, ${ }^{[29]}$ recorded that penconazole toxicity led to glomerular injury and subsequent renal impairment.Prolonged exposure to fungicides led to rapidly progressive glomerulonephritis and compensatory proliferation of glomerular cells ${ }^{[30]}$.

Electron microscopic study of penconazole treated group (group III) revealed disruption of the blood renal barrier, effacement of foot processes of podocytes and their detachment from the glomerular basement membrane. Similar results were detected by ${ }^{[31]}$.In addition, ${ }^{[32]}$ declared that structural changes of podocytes were associated with proteinuria. Moreover, ${ }^{[33]}$ stated that depletion of podocytes was associated with glomerulosclerosis in an experimental model of nephrosis in rat. Podocytes maintain homeostasis but excessive stress leads to their maladaptation, degeneration and detachment from glomerular basement membrane ${ }^{[34]}$.

${ }^{[35]}$ stated that loss of podocytes was associated with an increase in the number and volume of glomerular cells. However, ${ }^{[36]}$ declared that glomerular hypertrophy occurred in altered podocyte structure to achieve an increase of glomerular flow and filteration. Moreover, ${ }^{[37]}$ found that the increase in glomerular volume expansion led to podocyte stretching as a dynamic adaptation to glomerular volume enlargement.This high mechanical load led to angiotensin II synthesis and triggered apoptosis through TGF- $\beta$ production.

Microscopic study of cortical renal tubules of penconazole treated group of the present study revealed vacuolar degeneration and focal necrosis which were confirmed by a significant decrease of Bcl- 2 immunemarker. The intra-luminal acidophilic protein casts noticed in this study could be due to combination of the sloughed tubular cells with Tamm-Horsfall protein present in the lumen of tubules. Similar results were detected by ${ }^{[17]}$.

The lining epithelium of cortical collecting tubules was formed of principal (clear cells) that formed the majority of cells, the other less predominant cell type was dark (mitochondria rich) intercalated cells that were responsible for control of acid -base balance ${ }^{[38]}$

In penconazole treated group of the present study, there was an apparent increase in the number of intercalated cells with an apical organelle-free cytoplasmic blebbing. This was in agreement with ${ }^{[39]}$. The extension in the apical membrane area of the intercalated cells was attributed to the fusion of the intracellular tubulovesicles with the apical membrane to increase the active proton pump in case of metabolic acidosis, which occurred due to the toxic effect of penconazole on the lung structure and function ${ }^{[40]}$

In addition, ${ }^{[41]}$ declared that intercalated cells underwent proliferation in response to acute acidosis load. They also added that the epithelial lining of the cortical collecting tubules contained mitochondria- rich undifferentiated cells.

Renal fibrosis in penconazole treated group was detected in our study. This was confirmed by significant increase in both $\alpha$ SMA (the marker of mesenchymal cells) and the highly significant increase $(p<0.001)$ in percentage of the surface area of collagen. ${ }^{[42]}$ recorded that about $30 \%$ of fibroblasts were derived from tubular epithelium cells by a process called epithelial mesenchymal transition (EMT). They added that $35 \%$ of fibroblasts were derived from endothelial cells by a similar process called endothelial mesenchymal transition (EndMT). Moreover, ${ }^{[43]}$ stated that profibrotic growth factors as TGF- $\beta$ and chemokines derived from activated epithelial and endothelial cells were involved in renal fibrosis.

In our result, we also noticed presence of flattened cells with flattened nuclei, lining some renal tubules. This might be a regenerated tubular cells that not fully differentiated.

In penconazole treated group, presence of extraglomerular cellular proliferation beneath the parietal layer of Bowman's capsule and hypercelluarity of the interstitium were detected. This was in agreement with $^{[44]}$ who reported that the parietal layer of the renal capsule may function as a novel stem cell harboring for mesenchymal stem cell (MSC), capable of participating in the repair of renal injury. In addition, Barker et al. ${ }^{[45]}$ stated that the renal capsule acts as a potential stem cell niche. It serves as a reservoir for MSC (universal repair cells in adult tissues), which are quiescent under normal conditions but become recruited to the renal parenchyma after ischemia and injury. However, other reports have suggested that the renal tubules and renal capsule are the site of stem cells. They observed that the renal capsule contains stain - retaining cells which exhibited markers for mesenchymal stem cells ${ }^{[46]}$. Some investigators attributed this to the activation of several stem cell niches present in 
the kidney under oxidative stress caused by penconazole treatment ${ }^{[30]}$.

The biochemical findings obtained in the present study were substantiated with the histopathological changes in the kidney. A significant increase of plasma levels of urea and creatinine in penconazole treated rats was observed, indicating renal dysfunction and reduction in the glomerular filtration rate. This finding was in accordance with the previous study of El- Demerdash et al. ${ }^{[47]}$ who found increased plasma urea level in the kidney of rats exposed to methomyl, a carbamate pesticide. This also was in agreement with Badgujar et al. ${ }^{[48]}$ who demonstrated increased plasma creatinine and blood urea nitrogen levels in rats exposed to fipronil, a phenyl pyrazole insecticide. They also added that kidney function impairment as evident by the increase in plasma urea and creatinine concentrations could be attributed to oxidative damage and generation of reactive oxygen species (ROS) caused by penconazole toxicity.

In the current study, penconazole induced lipid peroxidation in the kidney of rats of group III as revealed by the significant increase in malondialdehyde (MDA) level, a LPO product. This was in accordance with the previous results of $\mathrm{Sakr}^{[49]}$ who have shown that mancozeb fungicide, induced oxidative stress in the liver of albino rats. The increased MDA level in animals of group III could be due to the excessive production of ROS caused by penconazole.

In this present study, there were asignificant decrease in the level of catalase (CAT) and superoxide dismutase(SOD) enzymes in penconazole treated group. Marked decrease in the level of the antioxidant enzymes, following acephate toxicity, a pesticide was recorded by Poovala et al.$^{[50]}$. The inhibition activity of penconazole on CAT and SOD and enhancement of lipid peroxidation was based on production of oxygen free radicals ${ }^{[1]}$.

Overall, our results suggested that the main mechanism underlying penconazole nephrotoxicity involves the production of ROS, resulting in subsequent formation of oxidative stress in the renal tissue. Increased production of ROS led to tissue damage as necrosis, apoptosis and fibrosis.

Concomitant administration of Nigella sativa oil with penconazole in group IV of the present study revealed an improvement in the structure of the glomeruli, renal tubules and the interstitium. This was in accordance with Abdel Moneim.$^{[10]}$ who reported that Nigella sativa oil decreased the tubular necrosis score and prevented the degenerative changes in the kidney tissues through blocking the oxidative stress pathways. Also, other researchers reported the nephroprotective effect of Nigella sativa oil against gentamycin - induced renal toxicity in rabbits Saleem et al. ${ }^{[52]}$

Nigella sativa showed anti-apoptotic action through significant decrease of Bcl-2 immune marker. Rastogi et al. ${ }^{[53]}$ assumed the probable anti-apoptogenic effect of Nigella might be through its antioxidant, immune modulatory and geno-protective mechanisms.

Significant decrease in collagen fibers of the renal interstitium was observed with administration of Nigella sativa oil in group IV. This came with Turkdogan et al. ${ }^{[54]}$ who reported that Nigella sativa hindered fibrosis-related coagulation necrosis, occurred in carbon tetrachlorideinduced liver damage through its immune modulator activity. The anti-fibrotic effect of Nigella sativa is through the action of Thymoquinone (TQ), the major active ingredient of Nigella sativa ${ }^{[55 ، 56]}$

Significant decrease in the serum urea and creatinine levels were observed with administration of Nigella in group IV. This go with Saleem et al. ${ }^{[53]}$ who stated that Nigella sativa oil lowered the values of serum creatinine and blood urea nitrogen in gentamycin associated nephrotoxicity in rabbits through blocking oxidative stress.

Interestingly, treatment with Nigella sativa oil improved oxidative stress marker and enzymatic antioxidant status of rats exposed to penconazole, indicating that this plant extract participated in the reduction of penconazole toxicity by decreasing oxidative stress through the ability of its antioxidant compounds to scavenge free radicals.

From all the mentioned data and from the results of our study, it is concluded that administration of Nigella sativa oil improved the oxidative damage and nephrotoxicity caused by penconazole. Further investigations will be done to elucidate the potential usefulness of this plant as a source of protective agents against drug toxicity in clinical trials.

\section{CONFLICTS OF INTEREST}

There is no conflict of interest to declare.

\section{REFERENCES}

1. Hou B, Wu L (2010): Safety impact and farmer awareness of pesticide residues. Food Agric Immunol.; 21:191-200. https://doi. org/10.1186/1472-6882-14-458

2. Goetz AK, Ren HZ, Schmid JE, Blystone CR, Thillainadarajah I, Best DS, Nichols HP, Strader LF, Wolf DC, Narotsky MG (2007): Disruption of testosterone homeostasis as a mode of action for the reproductive toxicity of triazole fungicides in the male rat. Toxicol Sci. ; 95:227-239.

3. Bhinder P1, Chaudhry A (2013): Mutagenicity Assessment of Organophosphatesusing Polymerase Chain Reaction-Restriction Fragment Length Polymorphism Assay.Toxicol Int.; Sep;20(3):25460. doi: 10.4103/0971-6580.121678.

4. Galal MK, Abdel Azim AK, Hanan AO and Ibrahim MA (2014): Vitamin E attenuates neurotoxicity induced by deltamethrin in rats The official journal of the International Society for Complementary Medicine Research (ISCMR); 14:458. 
5. Greim H, David S, Volker M ,Christian S (2015): Evaluation of carcinogenic potential of the herbicide glyphosate, drawing on tumor incidence data from fourteen chronic/carcinogenicity rodent studies Journal Critical Reviews in Toxicology ; Volume 45, - Issue 3; 54-90.

6. El-Sharkawy EE, El-Nisr NA (2013): Testicular dysfunction induced by penconazole fungicide on male albino rats. Comp ClinPathol.; 22:475-480.

7. Chaâbane M, Soudani N, Benjeddou K, Turki M, Ayadi MF, Boudawara T, Zeghal N, Ellouze GR(2015): The protective potential of Nitraria retusa on penconazole-induced hepatic injury in adult rats. Toxicol Environ Chem.; 97:1253-1264.

8. Ghorbel R, Zeghal N, Soudani N (2016): Improvement of heart redox states contributes to the beneficial effects of selenium against penconazole- induced cardiotoxicity in adult rats. Biol Trace Elem Res ;169:261-270.

9. Ben Amara I, Karray A, Hakim A, Ben Ali Y, Troudi A, Soudani , Boudawara T, Zeghal KM, Zeghal N (2013): Dimethoate induces kidney dysfunction, disrupts membrane-bound ATPases and confers cytotoxicity through DNA damage. Protective effects of vitamin E and selenium. Biol Trace Elem Res. ; 156:230-242.

10. Abdel-Moneim, A, Morsy BM, Mahmoud AM, Abo-Seif MI, Zanaty SH (2013): Beneficial therapeutic effects of Nigella sativa and/or Zingiber officinale in $\mathrm{HCV}$ patients in Egypt. Excli J.; 12: 943-955.

11. Hanafy MS, Hatem ME (1991): Studies on the antimicrobial activity of Nigella sativa seed (black cumin). J Ethnopharmacol.; 34(2-3):275-8.

12. El-Dakhakhny M, Mady N, Lembert N, Ammon HP (2002) : The hypoglycemic effect of Nigella sativa oil is mediated by extrapancreatic actions. Planta Med; May;68(5):465-6.

13. Salem ML (2005): Immunomodulatory and therapeutic properties of the Nigella sativa L. seed .IntImmunopharmacol.; (13-14):1749-70.

14. Abdulelah, HA, Zainal-Abidin, BA (2007): In vivo anti-malarial tests of $\mathrm{N}$. sativa (black seed) different extracts. Am. J. Pharmacol. Toxicol.; 2: 46-50.

15. Raval BP, Shah TG, Suthar MP, Ganure AL (2010) : Screening of Nigella Sativa seeds for antifungal activity. Ann Biolog Res.;1:164-171.

16. Kamarzaman S.M. , Shaban I.N., Abdul Rahman S (2014): The prophylactic effect of Nigella Sativa against cyclophosphamide in the ovarian follicles of matured adult mice: A preliminary study.The
Journal of Animal \& Plant Sciences ; 24(1):, Page: 81-88ISSN: 1018-708.

17. Chaâbane M1,2, Koubaa M3, Soudani N1, Elwej A1, Grati M4, Jamoussi K4, Boudawara T5, EllouzeChaabouni S2, Zeghal N (2017): Nitraria retusa fruit prevents penconazole-induced kidney injury in adult rats through modulation of oxidative stress and histopathological changes. Pharm Biol. ; Dec55(1):1061-1073. doi: $10.1080 / 13880209.2016 .1278455$.

18. Nishikimi M, Rao NA, Yog K (1972): Colormetric determination of superoxide dismutase activity. Biochem.Biophys. Res. ; Commun 46: 849-851.http://dx.doi.org/10.1016/ S0006-291X(72)80218-3.

19. Aebi, H. (1984) : Catalase in Vitro." Methods in Enzymology ;105: 121126.

20. Ohkawa H, Nobuko O, Yagi K (1979) :Assay for lipid peroxides in animal tissues by thiobarbituric acid reaction Analytical Biochemistry ; Volume 95 Issue 2, Pages 351-358.

21. Suvarna S K, Layton C, Bancroft J (2013): The Hematoxylin and eosin. Theory Practice of histological techniques. 7th ed. Ch. 10 and 11. Philadelphia: Churchill Livingstone of El Sevier; 179-220. http://dx.doi.org/10.1016/ b978-0-7020-4226-3.00010.

22. Jackson P, Blythe D (2013): Theory Practice of histological techniques. In SK. Suvarna, C. Layton JD. Bancroft (Eds. 7th ed. Ch. 18. Philadelphia: Churchill Livingstone of El Sevier;. Immunohistochemical techniques; 386-431. http://dx.doi. org/10.1016/b978-0-7020-4226-3.00018-4.

23. Dykstra K, Michael J, Laura E (2003): Biological Electron Microscopy Theory, Techniques, and Troubleshootingeffect of vitamin $\mathrm{E}$ and vitamin $\mathrm{C}$. Pest Biochem Physiol.; 118:10-18.

24. Parsons PP (2001): Mammalian toxicokinetics and toxicity of propiconazole. In: Handbook of pesticide toxicology. Academic Press Krieger; 8: $1743-1757$.

25. El-Sharkaway EE, El- Nasr NA (2013): Testicular dysfunction induced by penconazole fungicide on male albino rats. Comp. Clin. Pathol; 22: 475480. http: //dx.doi.org/ 10. 1007/s00580 -012-1435-4.

26. Nasr AY (2013): Morphological, biochemical, histological, and ultrastructural protective effects of misoprostol on cisplatin induced-hepatotoxicity in adult male rats. Saudi Med J.;34(12):1237-47.

27. Shah MD, Iqbal M (2010): Diazinon-induced oxidative stress and renal dysfunction in rats. Food ChemToxicol 48:3345-3353. 
28. Sakr S, El- Kenawy A ,El- Sahra D: Metiram induced nephrotoxicity in albino mice (2013): effect of licorice aqueous extract. Environ Toxicol.; 28:372-379.

29. Eissa FI, Zidan NA (2010): Haematological, biochemical and histo-pathological alterations induced by abamectin and Bacillus thuringiensis in male albino rats. Acta Biol.; Hung.61 (1): 33-44.

30. John AL, Bart AF (2015): The Evolution of Fungicide Resistance In advances in Applied Microbiology. ScienDirect.; 90: 29-92.

31. Schiffer M, Bitzer M, Roberts IS, Koop JB, Mundel P, Bottinger EP (2001): Apoptosis in podocytes induced by TGF-beta and Smad 7.J Clin Invest; 108: 807- 816.

32. Kerjaschki D (2001): Caught flat -footed: podocyte damage and the molecular bases of focal glomerulosclerosis. J Clin Invest.; 108: 15831587.

33. Kim YH, Goyal M, Kurnit D, Wharram B, Wiggins J , Holzman L ,Kershaw D (2001): Podocyte depletion and glomerulosclerosishavea direct relationship in the PAN- treated rat. Kidney Int.; 60: $957-968$

34. Michio N (2016): Podocyte injury and its consequences. Kidney International Official Journal of the international society of nephrology.; 89: 1221-1230.

35. Kuhlmann A, Haas CS, Gross ML, Reulbach U, Holzinger M, Schwarz U, Ritz E , Amann K (2004): 1,25 - Dihydroxyvitamin D3 decreases podocyte loss and podocyte hypertrophy in the subtotallynephrectomized rat. Am J Physiol Renal Physiol.; 28666: F526- F533.

36. Fassi A, Sangalli F, Maffi R, Colombi F, Mohamed EI, Brenner BM, Remuzzi G, Remuzzui A (1998): Progressive glomerular injury in the MWF rat is predicted by inborn nephron deficit. J Am SocNephrol, 9: 1399 -1406.

37. Durvasula RV, Petermann AT, Hiromura K, Blonski M , Pippin ,J Mundel P,Pichler R , Griffin S , Couser WG (2004): Activation of a local tissue angiotensin system in podocytes by mechanical strain. Kidney Int.; 65: 30 -39.

38. Ross MH , Pawlina W (2006): Histology A Text and Atlas with correlated cell and molecular biology .5th edition. 647- 666

39. Abdelrahim EA (2012): Histological study of the intercalated cells of the rat collecting ducts in response to an acute potassium bicarbonate load. Egypt J Histol; 35: $532-540$.
40. Chaâbane M1, Elwej A2, Ghorbel I2, Chelly S2, Mnif H3, Boudawara T3, EllouzeChaabouni S4, Zeghal N2, Soudani N2 (2018): Penconazole alters redox status, cholinergic function and lung's histoarchitecture of adult rats: Reversal effect of vitamin $\mathrm{E}$ doi: 10.1016/j.biopha..03.113.

41. Cicerello E, Merlo F, Maccatrozzo L (2010): Urinary alkalization for the treatment of uric acid nephrolithiasis. ArchivioItaliano di Urologia e Andrologia; 82: 145 -148.

42. Zavadil J and Bottinger EP (2005): TGF-beta and epithelial to mesenchymal transitions.. Oncogene; 24: $564-74$.

43. Pulskens WP, Rampanelli E, Teske GJ, Butter LM , Luirink IK (2010): TLR4 promotes fibrosis but attenuates tubular damage in progressive renal injury. J AmSocNephrol.; 21(8): 1299 -1308.

44. Hyeong CP, Kaoru Y, Mei CK, Jie N, Brian R (2010): Renal capsule as a stem cell niche. American Journal of Physiology. // https: // doi. Org/ 10.1152/ a J P renal. 00406.2009.

45. BarkerN, Rookmaaker G, Maarten B, K ujala P, Annie L, Snippert H, Tan S (2012): Lgr 5 +ve Stem/ Progenitor Cells Contribute to Nephron Formation during Kidney Development . CellReports.; 2 (3): $540-52$.

46. Park H C, Yasuda K, Kuo MC, Ni J, Ratliff B, Chander P, Goligorsky M S (2010): Renal capsule as a stem cell niche. AJP: Renal Physiology ; 298 (5): F1254. doi:10.1152/ajprenal.00406.2009. PMC 2867407

47. El-Demerdash FM, Yousef IM, Kedwany FS, Baghdadi HH (2004): Cadmium Induced Changes in Lipid Peroxidation, Blood Hema-tology, Biochemical Parameters and Serum Quality of Male Rats: Protective Role of Vitamin E and b-Carotene." Food and Chemical Toxicology ; 42: 1563-1571. http://dx.doi.org/10.1016/j. fct.2004.05.001.

48. Badgujar PC, Pawar NN, ChandratreGA,Telang AG, Sharma AK: Fipronil induced oxidative stress in kidney and brain of mice: protective effect of vitamin E and vitamin C. 2014; Pest Biochem Physiol. 118: 10-18.

49. Sakr SA: Ameliorative effect of ginger (Zingiberofficinale) on mancozeb fungicide induced liver injury in albino rats. Aust $\mathrm{J}$ Basic Appl Sci. 2007; 1:650-656.

50. Poovala VS1, Kanji VK, Tachikawa H, Salahudeen AK (1998): Role of oxidant stress and antioxidant protection in acephate-induced renal tubular 
cytotoxicity .Toxicol Sci. ; 46(2):403-9.

51. Wei QY, Chen WF, Zhou B, Yang L, Liu ZL (2006): Inhibition of lipid peroxidation and protein oxidation in rat liver mitochondria by curcumin and its analogues. Biochimica Et Biophysica; 1760: 70-77. http://dx.doi.org/10.1016/j. bbagen.2005.09.008.

52. Saleem UI, Ahmad B, Rehman K, Mahmood S, Alam M, Erum A (2012) : Nephro-protective effect of vitamin $\mathrm{C}$ and Nigella sativa oil on gentamicin associated nephrotoxicity in rabbits Pak J Pharm Sci; (4):727-30.

53. Rastogi L, Feroz S, Pandey BN, JagtapA,Mishra KP (2010): Protection against radiation-induced oxidative damage by an ethanolic extract of Nigella sativa L. nt J RadiatBiol ; 86: 719-731.
54. Turkdogan MK, Ozbek H, Yener Z, Tuncer I, UyganI,Ceylan E (2003): The role of Urticadioica and Nigella sativatheprevention of carbon tetrachloride induced hepatotoxicityin rats. PhytotherRes.; 17:942-6.

55. Bargi R, Asgharzadeh F, Beheshti F , Mahmoud H, Majid K (2017): Thymoquinone protects the rat kidneys against renal fibrosis. In RPS; 12(6): 479- 487.

56. El-Khouly D1, El-Bakly WM, Awad AS, ElMesallamy HO, El-Demerdash E (2012): Thymoquinone blocks lung injury and fibrosis by attenuating bleomycin-induced oxidative stress and activation of nuclear factor Kappa-B in rats Toxicology ; Dec 16;302(2-3):106-13. doi: 10.1016/j.tox..09.001 
الملخص العربى

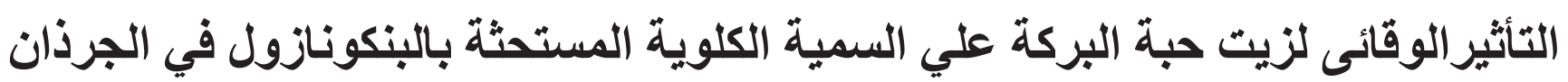

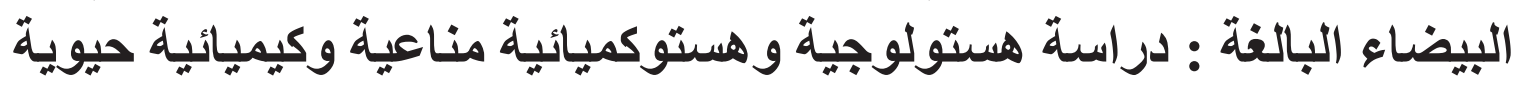 \\ نادية سعيد خير 1 ونرمين محمد نور الدين2}

1قسم الهستولوجي وبيولوجيا الخلية _2قسم التشريح - كلية الطب البشرى - جامعة المنوفية

المقدمة: يستخدم المبيد الفطري البنكونازول التابع لمجموعة التر ايازول علي نطاق واسع , فهو يستخدم في الزر اعة و الطب البشري و الطب البيطري. الجرعات العالية من البنكونازول تسبب السمية الكلوية والضرر الكلوي. فحبة البركة (الحبة السوداء) هي احدي النباتات المحلية .كما أن لها خصائص مضادة للالتهابات و مضادة لمرض السكري ومضادة للسرطان. الهدف من العمل: يهدف هذا العمل الي تقييم تأثير زيت حبة البركة علي السمية الكلوية في الفئران الناجمة عن التعرض لمبيد البنكونازول.

المواد و الطرق : تم استخدام ستون من ذكور الجرذان البيضاء البالغة حيث تم تقبيمهم الى أربع مجموعات متساوية: المجمو عة الأولى(الضابطة): تلقت فيها الفئران الماء المقطر, المجموعة الثانية:( حبة البركة) حيث تم اعطاؤها بالفم 0.2 مللي من زيت حبة البركة لكل 100 جم من وزن الفأر مرة واحدة في اليوم ولمدة ثلاث أيام في الأسبوع لمدة أربع أسابيع , المجمو عة الثالثة (المعالجة بالبنكونازول) : نم حقنهم في الغثاء البريتوني 67مللي جر ام من البنكونازول لكل كيلو جر ام من وزن الفأر , مرة واحدة في اليوم ولمدة ثلاث أيام في الأسبو ع لمدة أربع أسابيع , المجموعة الر ابعة:(المعطاة البنكونازول وزيت حبة البركة): أعطيت الفئران بنكونازول (67مللي جر املكل كيلوجرام) وزيت حبة البركة (0.2 لكل 100 جم) في وقت واحد ثناثة أيام أسبو عيا لمدة أربع أسابيع. في نهاية التجربة بتم اعداد أنسجة الكلي لتحضير ها للار اسات الكيميائية الحيوية و الدر اسات المجهرية الضوئية و المجهرية الدقيق. النتائج : كثف الفحص النسيجي لفئران مجموعة البنكونازول عن وجود ضمور في الكبيبات ، و اتساع الفضاء تحت المحفظة وفرط خلوية الخلايا الكبيبية. أدي انفصال الخلايا الوعائية و اضطر اب زوائدها الي ضعف الحاجز الكلوي الدموي. تم تأكيد الانحلال الأنبوبي و النخر بانخفاض ملحوظ في علامة المناعة بي سي ال 2.. زيادة الخلايا المقسمة لانابيب التجميع القشرية، كانت مؤشر ا علي الحماض الأيضي. كما تم تأكيد التليف الكلوي بزيادة ملحوظة في ألفا أكتين العضلات الملساء و ألياف الكو لاجين. وقد كثفت الدر اسة البيو كيميائية عن زيادة في مستوي المالوندالدهيد ، و انخفاض كاضي ف تركيز ات كل من انزيم ديسموناز الفائق و انزيم الكاتلاز . . أدي العلاج المنز امن بزيت حبة البركة الي تحسن وحجز التغيرات الناجمة عن مبيد البنكونازول. الاستنتاج: يمكن أن تعزي الخصائص المضادة للأكسدة لحبة البركة في التخفيف من حدة السمية الكلوية التي يسببها مبيد البنكونازول في الفئران. 